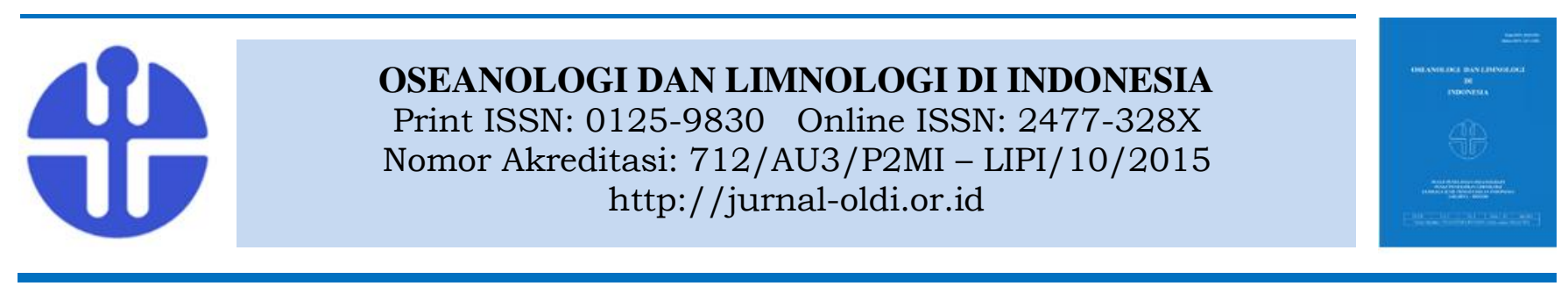

\title{
Pemetaan Mangrove Kepulauan Lease, Provinsi Maluku Menggunakan Data Multi- Temporal Dan Multi-Sensor Citra Satelit Landsat
}

\section{Mangrove Mapping Of The Lease Islands, Maluku Province Using Multi-Temporal And Multi-Sensor Of Landsat Satellite Images}

\author{
Sam Wouthuyzen ${ }^{1}$ dan Fasmi Ahmad ${ }^{2}$ \\ ${ }^{1}$ Loka Peningkatan Kompetensi Sumber Daya Manusia Oseanografi, Pulau Pari, LIPI \\ ${ }^{2}$ Pusat Penelitian Oseanografi LIPI, Jakarta \\ Email: swouthuyzen@yahoo.com
}

Submitted 13 February 2017. Reviewed 8 June 2017. Accepted 17 January 2018.

\begin{abstract}
Abstrak
Pemetaan mangrove di Kepulauan Lease, Provinsi Maluku Tengah telah dilakukan, tetapi hanya menggunakan satu citra satelit, sehingga sulit melihat dinamika perubahannya. Tujuan kajian ini adalah memetakan mangrove lima tahunan (1985-2015) menggunakan citra satelit Landsat multisensor (MSS, TM, ETM+ dan OLI) dan data lapangan. Klasifikasi terbimbing berbasiskan metoda maximum likelihood digunakan untuk mengklasifikasi mangrove dari habitat lainnya dan menghitung luasannya. Hasil menunjukkan bahwa Mangrove di Pulau Saparua dan Nusalaut terdiri atas 22 dan 13 jenis dengan sebaran terpanjang pada garis pantai Teluk Tuhaha, karena ada pasokan air tawar dari sungai, sedangkan sisanya tumbuh pada substrat keras di rataan terumbu. Hasil uji rata-rata dari akurasi keseluruhan peta cukup baik $(74,7 \%)$, kecuali untuk peta yang dihasilkan Landsat-5 TM (1995) dan Landsat-8 OLI (2015), karena terkontaminasi tutupan awan/haze. Luas mangrove di seluruh lokasi kajian selama 30 tahun relatif stabil, karena terproteksi oleh kearifan lokal "Kewang". Adapun bias tertinggi sebesar 11,4\% yang membuat fluktuasi luas mangrove bertambah atau berkurang bukan disebabkan pemanfaatan atau konversi mangrove, melainkan karena pengaruh awan dan geometrik citra dengan sensor yang berbeda. Ke depan, metoda OBIA layak untuk dicoba karena tampaknya dapat menghasilkan peta mangrove dengan akurasi yang lebih baik.
\end{abstract}

Kata kunci: Mangrove, Landsat, Multi-temporal, Mullti-sensor, Peta, Kepulauan Lease

\begin{abstract}
Mangrove mapping in the Lease Islands, Maluku Province has been done, but using only a single date satellite image. Therefore, it is difficult to know the dynamics of their changes. The aim of this study is to map mangroves every 5 year (1985-2015) using multi-sensors (MSS, TM, ETM+ and OLI) of Landsat and field data. Supervised classification using maximum likelihood was used for classifying mangrove and other habitats, and counting their areas. Results showed that mangrove in the Saparua and Nusalaut Islands, consisted of 22 and 13 species, respectively, with
\end{abstract}


the longest distribution along the cost line of Tuhaha Bay due to freshwater supplay from the surrounding river, while the rest are grown in the hardy reef flat substrates. The mean overall acurracies of the maps was good enough (74.7\%), except for one Landsat-5 TM and Landat-8 OLI because of the influences of cloud cover or haze. During 30 years, the areas of mangrove are relatively stable since they are protected by local wisdom called "Kewang". The highest bias of $11.4 \%$ that made the areas of mangrove increase or decrease was not due to the utilization or conversion of mangrove, but mainly due to the influences of cloud cover/haze and the geometric differences among Landsat sensors. In the near future, the OBIA method should be try, because it seems to be able to produce mangrove maps with better accuracy.

Keywords: Mangrove, Landsat, Multi-temporal, Multi-sensors, maps, Lease Islands.

\section{Pendahuluan}

Indonesia memiliki keaneka-ragaman jenis mangrove yang sangat tinggi, yakni sekitar 38 jenis (Hutomo and Moosa 2005), sedangkan Pramudji (2008) menyatakan ada 75 jenis yang mewakili 24 famili dan 41 genera, namun Snedaker (1984) mecatat paling sedikit ada 202 jenis mangrove, 43 jenis diantaranya adalah mangrove sejati (true mangrove), dan sisanya mangrove ikutan/tidak sejati (associated/pseudo mangroves), sedangkan Sukarjo and Alongi (2012) menyebutkan ada 92 jenis mangrove sejati. Vegetasi mangrove tersebut dalam bentuk pohon, palma, tumbuhan merambat, dan pakis-pakisan (Giesen et al. 2006).

Luas mangrove Indonesia terbesar di dunia, yaitu $27 \%$ atau $75 \%$ mangrove Asia Tenggara (Pramudji 2008), namun luasnya ini berbeda-beda dari tahun ke tahun. Tahun 1978 diperkirakan 3,6 - 3,7 juta ha (Soemodihardjo et al. 1993; Snedaker 1984; Burbridge dan Koesoebiono 1980). Tahun 1982-1984 berkisar 4,2 - 4,4 juta ha (Cholik dan Poernomo 1986; Darsidi 1984). Pada tahun 1993-2000 an turun menjadi 2,40 juta ha (FAO 2007; Kitamura et al. 1997; Giesen 1993). Tahun 2010, Bakosurtanal yang berubah namanya menjadi Badan Informatika dan Geospasial (BIG) menduga luas mangrove sekitar 3,2 juta ha berdasarkan 199 citra satelit Landsat-7 ETM (Hartini et al. 2010). Luas ini telah menjadi acuan resmi. Luas ekstrim rendah dikeluarkan oleh Wetland International, yaitu hanya sekitar 1,5 juta ha (Pramudji 2008). Perbedaan ini menunjukkan sulit menentukan luas mangrove di Indonesia.

Propinsi Maluku Tengah terdiri dari ratusan pulau besar dan kecil serta teluk. Mangrove bisa tumbuh baik karena terlindung dan mendapat pasokan air tawar atau tumbuh di atas pulau-pulau karang. Pemetaan dan pemantauan kondisi mangrove Provinsi Maluku telah dilakukan secara intensif di Teluk Kotania (Pulau Seram barat) memggunakan data satelit Landsat multi-temporal tahun 19721986 (Wouthuyzen et al. 2002; Wouthuyzen dan Sapulete 1995; Wouthuyzen 1991; Wouthuyzen et al. 1990), dan di Teluk Kayeli (Pulau Buru) tahun 1986-1996 (Wouthuyzen 1997; Wouthuyzen et al. 2002). Peta-peta mangrove di kedua teluk ini kembali lagi dibuat tahun 2000an memakai data dari citra ALOS AVNIR-2 (Wouthuyzen 2011). Berdasarkan peta-peta tersebut, luas dan dinamika perubahan mangrove dapat diketahui yang selanjutnya dipakai untuk perencanaan dan pengelolaan sumber daya pesisir, seperti pengelolaan kepiting bakau, Scylla serata (Supriyadi dan Wouthuyzen 2001) dan analisis valuasi ekonomi di Teluk Kotania (Supriyadi dan Wouthuyzen 2005).

Meskipun demikian, pemetaan dan pemantauan hutan mangrove secara multitemporal di banyak lokasi di Propinsi Maluku Tengah, seperti Kepulauan Lease (Pulau Haruku, Saparua dan Nusalaut) masih sangat jarang dilakukan. Kalay dan Waas (2005) mengkaji kerapatan vegetasi bakau di Pulau Nusalaut, memakai Citra Landsat-7 ETM+. Satelit yang sama juga dipakai oleh Waas dan Nababan (2010) untuk memetakan mangrove melalui analisis Indeks Vegetasi di Pulau Saparua, namun semua kajian ini terbatas hanya pada penggunaan satu citra satelit saja, sehingga belum bisa menentukan dinamika kondisi mangrove dalam jangka waktu panjang. Oleh karena itu, tujuan kajian ini adalah memetakan, dan memantau kondisi mangrove setiap lima tahunan di Pulau-Pulau Lease, khususnya di Pulau Saparu dan Nusa Laut serta sebagian Pulau Haruku menggunakan data multi-temporal dari berbagai citra satelit 
Landsat dengan berbagai sensor, yakni Multi Spectral Scanner/MSS (Landsat-5), Thematic Mapper/TM (Landsat-5), Enhanced Thematic Mapper Plus/ETM+ (Landsat-7) dan Operational Land Imager/OLI (Landsat-8).

\section{Metodologi}

\section{Lokasi dan waktu kajian}

Kajian ini dilakukan di kepulauan Lease yang terdiri atas tiga pulau utama, yaitu Pulau Haruku, Saparua dan Nusalaut dan sebuah pulau kecil yakni Pulau Maulana (Gambar 1). Kajian ini terdiri atas dua tahapan, yaitu: 1). Pengamatan lapangan untuk mendapatkan data keaneka-ragaman jenis, nilai penting (NP) serta kerapatan mangrove yang dilakuan di Teluk Tuhaha dan Teluk Saparua (Pulan Saparua) pada bulan September 2006 dan di Pulau Nusalaut bulan Oktober 2009. 2). Pemetaan dan pemantauan serta analisis kondisi mangrove memakai data multitemporal citra satelit Landsat lima tahunan.

\section{Pengumpulan data mangrove dan analisis}

Pengamatan di lapangan dilakukan dengan transek yang ditarik tegak lurus garis pantai hingga batas akhir hutan mangrove di darat. Pada garis transek dibuat petak berukuran $10 \mathrm{~m}$ x $10 \mathrm{~m}$ untuk menghitung jumlah tegakan mangrove yang termasuk dalam kategori sebagai pohon (diameter setinggi dada $>10$ $\mathrm{cm}$ ). Dalam kotak 10x10 m dibuat lagi kotak berukuran $5 \times 5 \mathrm{~m}$ untuk menghitung jumlah anakan (belta) mangrove (diameter 2-10 cm).

Pengamatan mangrove di Pulau Saparua dilakukan di Teluk Tuhaha dan Saparua. Pengamatan di Teluk Tuhaha dilakukan pada 2 jalur transek dengan panjang transek berkisar 200-300 m (20-30 plot) dari garis pantai hingga batas vegetasi darat, disamping itu dilakukan pula pengamatan bebas di luar garis transek, sedangkan di Teluk Saparua, transek tidak dilakukan, karena mangrove tidak membentuk komunitas melainkan berupa spot-spot tegakan, sehingga pengamatan dilakukan secara bebas di 21 titik pengamatan, yaitu masing-masing di Pantai Kesuri, Desa Booi (sembilan titik), Pantai Sero, Desa Booi (delapan titik) dan Pantai Waisisil, Desa Tiouw (empat titik). Komunitas mangrove di Pulau Nusalaut, walaupun tidak lebat, namun pengamatan dilakukan menggunakan transek di enam desa (Desa Titawaai, Sila/Leinitu, Nalahia, Ameth, Akoon dan Abubu) (Gambar 1). Data hasil pengamatan mangrove lalu dianalisis menurut Cox (1967), yaitu dengan menghitung Kerapatan (K), Kerapatan relatif (KR), Frekuensi relatif (FR), Dominasi relatif (DR) serta Nilai Penting (NP).

$\mathrm{KR}=$ Kerapatan suatu jenis mangrove / Kerapatan seluruh jenis mangrove $\mathrm{x} 100$ $\mathrm{FR}=$ Frekuensi suatu jenis mangrove / Frekuensi seluruh jenis mangrove $\mathrm{x} 100$ $\mathrm{DR}=$ Dominasi suatu jenis mangrove / Dominasi seluruh jenis mangrove $\mathrm{x} 100$ Dominasi dihitung berdasarkan basal area, yaitu dengan mengukur keliling batang pohon setinggi dada dari setiap individu mangrove dalam setiap plot, dan Nilai Penting

$$
\mathrm{NP}=\mathrm{KR}+\mathrm{FR}+\mathrm{DR}
$$

\section{Data Citra Landsat dan pra-analisis}

Pemetaan mangrove menggunakan tujuh set data multi-temporal dari berbagai citra satelit Landsat dengan sensor yang berbeda (Tabel 1). Data ini diperoleh dari U.S. Geological Survey Visualization Viewer atau earth explorer yang bisa diunduh secara gratis melalui jaringan http://glovis.usgs. Langkah awal analisis data citra Landsat-5 MSS, Landsat-5 TM, Landsat-7 ETM+ dan Landsat8 OLI (Path/Row: 108/063), yaitu melakukan pemotongan citra (cropping) pada area yang menjadi pusat kajian saja, yang mencakup Pulau Saparua dan Nusalaut serta sebagian kecil (sisi tenggara) Pulau Haruku (Gambar 1).

Karena pada kajian ini digunakan data multi-temporal yang diperoleh dari berbagai macam sensor satelit Landsat, maka sebelum analisis lebih lanjut, dilakukan beberapa koreksi, antara lain:

(1). Koreksi Geometrik, yaitu koreksi agar citra satelit Landsat yang digunakan dalam kajian ini, yang terdiri dari berbagai sensor memiliki koordinat geografis yang sama, sehingga seluruh citra dapat dibandingkan satu dengan lainnya. Koreksi geometrik dilakukan dengan cara mengkonversi koordinat citra satelit dari sensor MSS, TM, ETM+ (Landsat-5 dan -7) ke koordinat sensor OLI (Landsat-8), karena koordinat sensor OLI relatif memiliki ketelitian koordinat lebih tinggi sesuai dengan koordinat di lapangan dibandingkan sesnor satelit Landsat lainnya.

(2). Koreksi atmosferik, yaitu koreksi yang disebabkan akibat pengaruh zat-zat di 
atmosfir (gas, butiran air, debu dan lainnya) yang kondisinya berbeda pada setiap perekaman citra satelit. Koreksi atmosferik dilakukan dengan merujuk prosedur sederhana, yaitu Dark Object Subtraction (DOS) (USGS and NOAA 1984; Chavez 1988; Song et al. 2001; Gillmore et al. 2015).

(3). Koreksi radiometrik, yaitu koreksi yang dilakukan dengan cara mengkonversi Nilai Digital (ND) terkoreksi menjadi nilai radians (NR) $\left[\mathrm{Watt} /\left(\mathrm{m}^{2} \mathrm{x}\right.\right.$ sr $\left.\left.\mathrm{x} \mu \mathrm{m}\right)\right]$. Hal ini perlu dilakukan karena adanya perbedaan sensor dan umur sensor yang pajang, seperti sensor TM yang telah beberapa kali dikalibrasi. Dengan mengkonversi ND menjadi NR, maka seluruh sensor yang digunakan memiliki satuan/unit yang sama
[Watt $/\left(\mathrm{m}^{2} \mathrm{x}\right.$ sr $\left.\mathrm{x} \mu \mathrm{m}\right)$ ], sehingga dapat dibandingkan antara satu sensor dengan sensor lainnya.

Konversi DN menjadi NR menggunakan persamaan berikut (Chander, et al. 2007):

$$
Q(N R)=\text { Gain } \times L \lambda+\text { Bias },
$$

$Q$ adalah Nilai Radians (NR) terkoreksi citra satelit pada suatu Band; Gain $(\mathrm{G})$ dan Bias (B) adalah koefisien kalibrasi untuk mengubah ND menjadi NR dari setiap sensor Landsat (Tabel 2). $L \lambda$ adalah ND suatu band. Nilai $G$ dan B untuk setiap Band diperoleh dari header (meta data) citra Landsat yang dipakai. Koreksi geometrik, atmosfir dan radiometik tersebut memungkinkan kita bisa membandingkan peta mangrove yang dihasilkan dari waktu ke waktu, walaupun data diperoleh dengan kondisi atmosfir dan dari sensor satelit Landsat yang berbeda

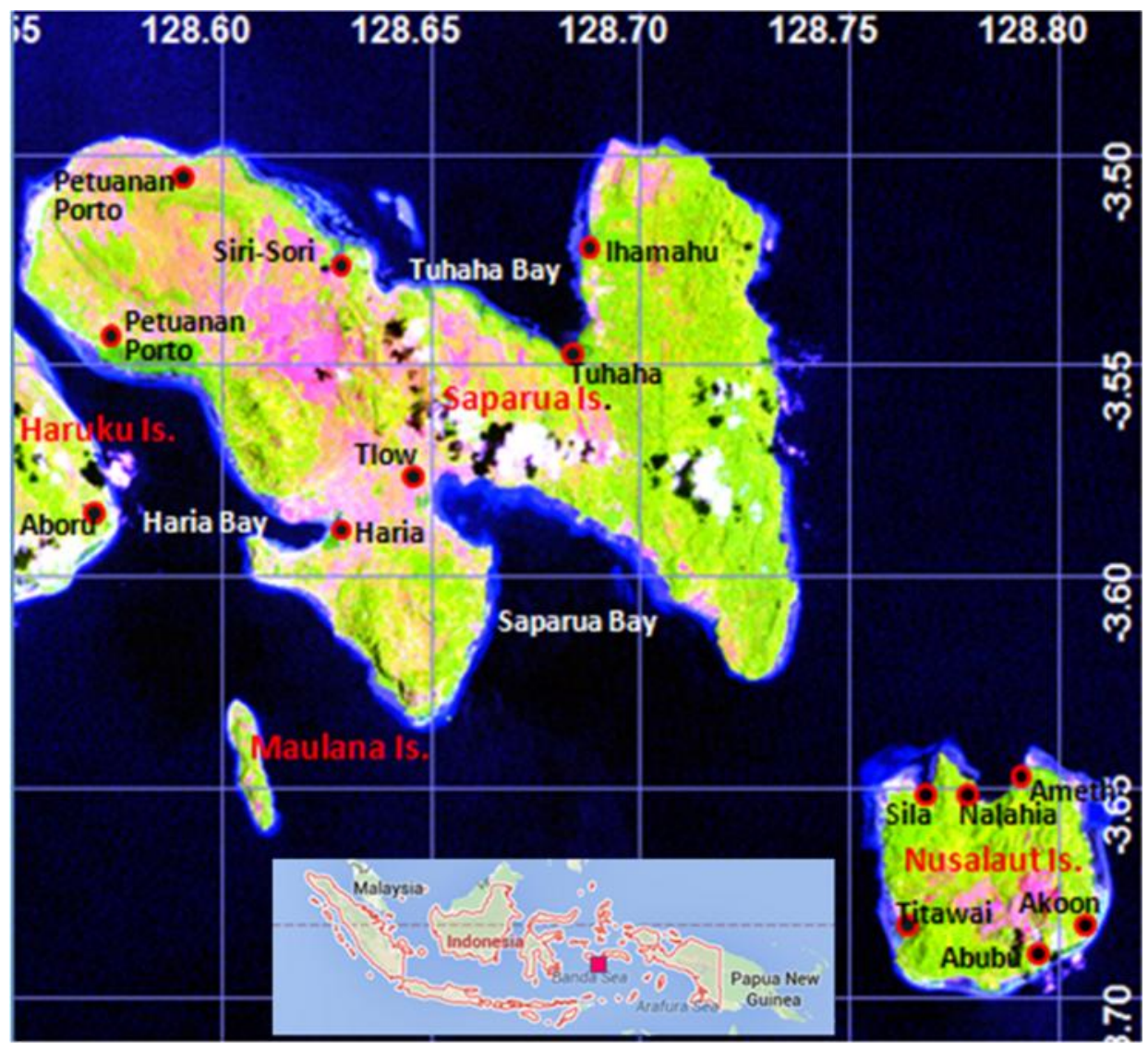

Gambar 1. Peta Kepulauan Lease. Titik merah menunjukkan lokasi pengamatan mangrove. Figure 1. Map of Lease Islands. Red circles indicate the observation sites of mangrove. 
Tabel 1. Data multi-temporal citra satelit Landsat yang digunakan dalam kajian ini. Table 1. Multi-temporal of Landsat satellites data used in this study.

\begin{tabular}{|c|l|l|c|c|c|c|}
\hline No. & Satellite images & \multicolumn{1}{|c|}{ Image ID No. } & Path & Row & $\begin{array}{c}\text { Acquired } \\
\text { date }\end{array}$ & $\begin{array}{c}\text { Cloud cover } \\
\text { in land (\%) }\end{array}$ \\
\hline 1. & Landsat-5 MSS & LM51080631985062ASA00 & 108 & 063 & $1985-03-03$ & 25 \\
\hline 2. & Landsat-5 TM & LT51080631990348ASA00 & 108 & 063 & $1990-12-14$ & 27 \\
\hline 3. & Landsat-5 TM & LT51080631995058DKI00 & 108 & 063 & $1995-02-27$ & 0 \\
\hline 4. & Landsat-7 ETM+ & LE71080632000304ASA00 & 108 & 063 & $2000-10-30$ & 17 \\
\hline 5. & Landsat-5 TM & LT51080632005069ASA01 & 108 & 063 & $2005-03-10$ & 9 \\
\hline 6. & Landsat-5 TM & LT51080632010035ASA00 & 108 & 063 & $2010-02-04$ & 13 \\
\hline 7. & Landsat-8 OLI & LC81080632015113LGN00 & 108 & 063 & $2015-04-23$ & 19 \\
\hline
\end{tabular}

Tabel 2. Konversi ND menjadi NR [Watt/( $\mathrm{m}^{2} \mathrm{x}$ sr $\mathrm{x}$ m)] dari berbagai sensor pada satelit Landsat. Table2. Conversion of Digital Number to Radiance NR [Watt/( $\left.\left.\mathrm{m}^{2} \mathrm{x} \mathrm{sr} x \mathrm{~m}\right)\right]$ from various sensors of Landsat Satellites

\begin{tabular}{|c|c|c|c|c|c|c|c|c|c|c|}
\hline \multirow[t]{2}{*}{ BAND } & \multicolumn{2}{|c|}{ Lsndsat-5 MSS } & \multicolumn{2}{|c|}{$\begin{array}{l}\text { Landsat-5 TM } \\
01 \text { May } 1984 \sim \\
01 \text { Apr } 2007\end{array}$} & \multicolumn{2}{|c|}{$\begin{array}{l}\text { Landsat-5 TM, } \\
02 \text { Apr 2007 up } \\
\text { to now }\end{array}$} & \multicolumn{2}{|c|}{ Landsat-7 ETM+ } & \multicolumn{2}{|c|}{ Landsat-8 OLI*) } \\
\hline & Gain & Bias & Gain & Bias & Gain & Bias & Gain & Bias & Gain & Bias \\
\hline 1 (Biru) & --- & --- & 0.6713 & -2.1931 & 0.7658 & -22858 & 0.7797 & -6.9787 & 0.0131 & -65.3415 \\
\hline 2 (Hijau) & 0.85945 & 1.64055 & 1.3222 & -4.1622 & 1.4482 & -4.2882 & 0.7988 & -7.1988 & 0.0120 & -60.2116 \\
\hline 3 (Merah) & 0.63346 & 2.06654 & 1.0440 & -2.2140 & 1.0440 & -2.2140 & 0.6217 & -5.6217 & 0.0102 & -50.7735 \\
\hline 4 (IR dekat) & 0.53386 & 4.16614 & 0.8760 & -2.3806 & 0.8760 & -2.3806 & 0.9693 & -6.0693 & 0.0062 & -31.0711 \\
\hline 5.(IR tengah) & 0.45118 & 2.44882 & 0,1204 & -0.4904 & 0,1204 & -0.4904 & 0.1262 & -1.1266 & 0.0015 & -7.7271 \\
\hline
\end{tabular}

*) Remark: For Landsat-8, the Gain and Bias values are subject to change according to the date of acquision. Thus, these values are for Landsat-8 OLI acquired on April 23, 2015. Gain and Bias values for other date can be found in the meta data file.

\section{Pemetaan mangrove}

Mangrove dipetakan menggunakan lima band (saluran) yang berada pada panjang gelombang biru/Band-1 (0,45-0,52 $\mu \mathrm{m})$, hijau/Band-2 (0,53-0,59 $\mu \mathrm{m})$, merah/Band-3 $(0,63-0,69 \mu \mathrm{m})$, infra merah dekat/NIR/Band-4 $(0,85-0,88 \mu \mathrm{m})$, dan infra merah tengah/SWIR/ Band-5 (1,57-1,65 $\mu \mathrm{m})$, kecuali untuk sensor MSS yang hanya terdiri atas empat band, dimana Band biru tidak tersedia (Tabel 2). Untuk membuat citra komposit yang bisa memperjelas komponen habitat pada citra Landsat, berupa komponen perairan (pasir dan rataan terumbu karang, baik yang dangkal, maupun yang dalam) serta komponen darat (mangrove, vegetasi darat, lahan terbuka dan lainnya), dipakai prosedur yang didasarkan atas pengalaman pribadi. Prosedur tersebut adalah: mengekstrak nilai radians (NR) maksimum antara Band Biru dan Hijau, Band Hijau dan Merah, serta Band Merah dan NIR yang masing-masing menjadi band baru. Buat citra komposit alami menggunakan citra ekstraksi NR maksimum Band Biru dan Hijau sebagai
Band Biru; Citra NR maksimum Band Hijau dan Merah sebagai Band Hijau, serta citra NR maksimum Band Merah dan NIR sebagai Band Merah. Citra composit baru (Gambar 2) menunjukkan dengan jelas masing-masing komponen habitat, karena NR maksimum Band Biru dan Hijau memiliki daya peneterasi di lingkungan perairan yang lebih tinggi, sehingga komponen habitat perairan dapat terpetakan dengan baik, sedangkan NR maksimum band Hijau dan Merah serta Band Merah dan Infra Merah dekat sangat baik memetakan komponen darat termasuk mangrove yang menjadi topik bahasan utama pada kajian ini.

Gambar 2 memperlihatkan komponen beberapa habitat, khususnya mangrove yang selanjutnya dipakai sebagai training area untuk mengklasifikasi habitat secara terbimbing (supervised classification). Analisis maximum likelihood (ML) menggunakan empat band citra Landsat (Biru, Hijau, Merah dan NIR) selanjutnya dipakai dalam klasifikasi habitat di lokasi kajian. Seluruh prosedur analisis citra 
satelit Landsat dilakukan memakai modulmodul program yang ada pada piranti lunak IDRISI Selva (versi 17).
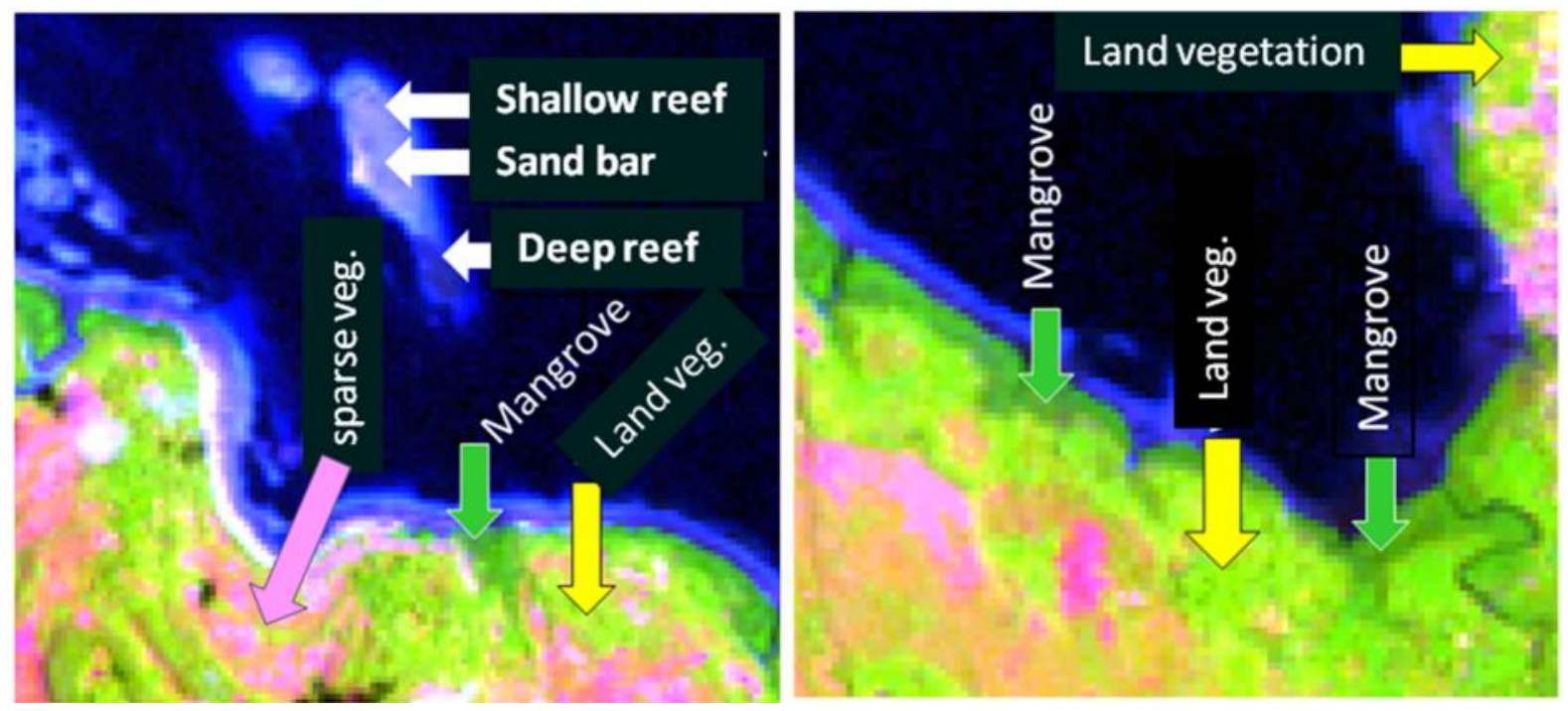

Gambar 2. Citra komposit yang dihasilkan dari Nilai Radians/NR Maksimum Band 1 dan 2 (Biru),Band 2 dan 4 (Hijau) dan Band 3 dan 5 (Merah). Lihat Gambar 1.

Figure 2. Composite images generate from Radiance values of Band 1 and 2 (Blue); Band 2 and 4 (Green) and Band 3 and 5 (Red). See figure1.

\section{Hasil}

\section{Pengamatan mangrove lapangan}

Hasil pengamatan mangrove dari lapangan, baik pada jalur transek maupun di luar jalur (pengamatan bebas) di Pulau Saparua, yaitu Teluk Tuhaha (dua transek) dan Teluk Saparua (21 titik pengamatan bebas) serta di enam desa di Pulau Nusalaut (Desa Titawaai, Sila/Leinitu, Nalahia, Ameth, Akoon dan Abubu) menunjukkan bahwa di setiap lokasi pengamatan ada 22 dan 13 jenis mangrove mewakili 15 famili (Tabel 3). Nilai Penting (NP) hasil perhitungan Kerapatan Relatif (KR), Frekuensi Relatif (FR) dan Dominasi Relatif (DR) untuk Pulau Saparua dan Nusa laut masing-masing disajikan pada Tabel 4 dan 5 . Dari Tabel 3, 4 dan 5 terlihat bahwa keanekaragaman jenis mangrove di kedua Pulau berbeda. Mangrove di Pulau Saparua lebih beragram (22 jenis) daripada di Pulau Nusalaut (13 jenis). Mangrove di Pulau
Saparua juga memiliki keanekaraganan jenis yang berbeda antara Teluk Tuhaha dan Teluk Saparua. Pada jalur transek di Teluk Tuhaha ditemukan ada 10 jenis mangrove, belum termasuk jenis di luar jalur transek. Sebaliknya, komunitas mangrove di Teluk Saparua hanya berupa spot-spot kecil dengan jumlah total lima jenis pada 21 lokasi pengamatan, sehingga transek tidak dapat dilakukan, terkecuali pengamatan bebas (Tabel 4). Perbedaan keanekaragaman jenis mangrove di Teluk Tuhaha dan lokasi lainnya karena adanya sungai berukuran sedang (Wai Ila) dan alur-alur air tawar, sehingga mangrove terkonsentrasi di lokasi-lokasi tersebut (Desa Tuhaha, Ihamahu, Kampung Mahu, dan Dusun Pia).

Lebih lanjut, jika dilihat dari Nilai Penting (NP) mangrove, yaitu nilai yang mengindikasikan dominasi, kemunculan dan kerapatan suatu jenis mangrove di suatu lokasi, maka terlihat jelas bahwa mangrove di Teluk Tuhaha memiliki NP yang lebih tinggi. 
Tabel 3. Keanekaragaman jenis mangrove di Kepulauan Lease (Pulau Saparua dan Nusalaut) Table 3. Mangrove diversity in the Lease Islands (Saparua and Nusalaut Islands)

\begin{tabular}{|c|c|c|c|c|c|}
\hline No & Family & No Species & Code & Saparua Island & Nusalaut Island \\
\hline \multirow[t]{7}{*}{1.} & Rhyzophoraceae & 1. Rhyzophora apiculata & $R h y \_a$ & + & + \\
\hline & & 2. Rhyzophora mucronata & $R h y \_m$ & + & - \\
\hline & & 3. Rhyzophora stylosa & $R h y \_S$ & + & - \\
\hline & & 4. Bruguiera gymnorrhiza & $B r u \_g$ & + & + \\
\hline & & 5. Bruguiera sexangula & $B r u \_s$ & + & - \\
\hline & & 6. Ceriops decandara & Cer_d & + & - \\
\hline & & 7. Ceriops tagal & Cer_t $t$ & + & + \\
\hline \multirow[t]{2}{*}{2.} & Soneratiaceae & 8. Sonneratia alba & Son_a & + & + \\
\hline & & 9. Sonneratia casiolaris & Son_c & + & + \\
\hline 3. & Meliaceae & 10. Xylocarpus granatum & $X y l \_g$ & + & + \\
\hline \multirow[t]{2}{*}{4.} & Myrsinaceae & 11. Aegiceras corniculatum & Aeg_c & + & + \\
\hline & & 12. Aegiceras floridium & Aeff $f$ & - & + \\
\hline 5. & Combretaceae & 13. Lumnitzera littorea & Lum_l & + & - \\
\hline 6. & Bombacaceae & 14. Camptostemon schultzii & Cam_s & + & - \\
\hline 7. & Euphorbiaceae & 15. Excoecaria agalocha & Exo_a & + & - \\
\hline 8. & Sterculiaceae & 18. Heritiera littoralis & Her_l & + & + \\
\hline 9. & Arecaceae & 17. Nypa fruticans & $N y p \_f$ & + & - \\
\hline 10. & Malvaceae & 18. Hisbiscus tiliaceus & His_t & + & + \\
\hline 11. & Ptridaceae & 19. Acrostichum aureum & Acr_a & + & + \\
\hline 12. & Fabaceae & 20. Pongamia pinata & Pon_p & + & - \\
\hline 13. & Pandanaceae & 21. Pandanus tectorius & $P a n \_t$ & + & - \\
\hline & Acanthaceae & 22. Acanthus ilicifolius & Acn_i & + & - \\
\hline & & 23. Dolicandrone spathaceae & Dol_s & - & + \\
\hline
\end{tabular}

Tabel 4. Keaneka ragaman, Nilai Penting (NP) dan Kerapatan (tegakan $/ \mathrm{m}^{2}$ ) rata-rata mangrove pada jalur transek (Teluk Tuhaha) dan pada pengamatan bebas (Teluk Saparua), Pulau Saparua Tahun 2006 (lihat Tabel 3 untuk kode spesies).

Table 4. Mangrove diversity, Important Values (IV), and Density (trees $/ \mathrm{m}^{2}$ ) in the transect of Tuhaha Bay and free observations (Saparua Bay), Saparua Island in 2006 (see Table 3 for species code).

\begin{tabular}{|c|c|c|c|c|c|c|c|c|c|c|c|c|c|c|c|c|c|c|c|c|c|c|c|c|c|}
\hline \multirow{4}{*}{$\begin{array}{l}\text { Species } \\
\text { Code }\end{array}$} & \multicolumn{4}{|c|}{ Tuhaha Bay } & \multicolumn{21}{|c|}{ Saparua Bay } \\
\hline & \multicolumn{4}{|c|}{ Villages of Pia-1 dan 2} & \multicolumn{9}{|c|}{ Kesuri Beach, Booi Village, } & \multicolumn{8}{|c|}{ Sero Beach, Booi Village } & \multicolumn{4}{|c|}{$\begin{array}{l}\text { Waisisi Beachl, } \\
\text { Tiouw Village }\end{array}$} \\
\hline & \multicolumn{2}{|c|}{ IV } & \multicolumn{2}{|c|}{ Density } & \multirow{2}{*}{1} & \multirow{2}{*}{2} & \multirow{2}{*}{3} & \multirow{2}{*}{4} & \multirow{2}{*}{5} & \multirow{2}{*}{6} & \multirow{2}{*}{7} & \multirow{2}{*}{8} & \multirow{2}{*}{9} & \multirow{2}{*}{$\begin{array}{l}1 \\
0\end{array}$} & \multirow{2}{*}{$\begin{array}{l}1 \\
1\end{array}$} & \multirow{2}{*}{$\begin{array}{l}1 \\
2\end{array}$} & \multirow{2}{*}{$\begin{array}{l}1 \\
3\end{array}$} & \multirow{2}{*}{$\begin{array}{l}1 \\
4\end{array}$} & \multirow{2}{*}{$\begin{array}{l}1 \\
5\end{array}$} & \multirow{2}{*}{$\begin{array}{l}1 \\
6\end{array}$} & \multirow{2}{*}{$\begin{array}{l}1 \\
7\end{array}$} & \multirow{2}{*}{$\begin{array}{l}1 \\
8\end{array}$} & \multirow{2}{*}{$\begin{array}{l}1 \\
9\end{array}$} & & 2 \\
\hline & tree & seed & tree & seed & & & & & & & & & & & & & & & & & & & & 0 & 1 \\
\hline Son_a & 79 & 15 & 141 & 56 & + & - & - & - & - & - & - & - & - & + & + & + & + & + & - & - & - & - & - & - & + \\
\hline Son_c & 7 & 0 & 13 & 0 & - & - & - & - & - & - & - & - & - & - & - & - & - & - & - & - & - & - & - & - & - \\
\hline Son_sp & - & - & - & - & - & + & + & - & + & + & + & + & + & - & - & - & - & - & - & + & + & + & + & + & + \\
\hline Rhi_a & 138 & 107 & 362 & 433 & - & - & - & + & + & - & - & - & - & - & + & & + & - & - & - & - & - & - & + & + \\
\hline Rhi_s & 9 & 3 & 12 & 12 & - & - & - & - & - & - & - & - & - & - & - & - & - & - & + & - & - & - & - & + & - \\
\hline$B r u \_g$ & 22 & 26 & 24 & 240 & - & - & - & - & - & - & - & - & - & - & - & - & - & - & - & - & - & - & - & - & - \\
\hline$B r u \_c$ & 15 & 12 & 15 & 56 & - & - & - & - & - & - & - & - & - & - & - & - & - & - & - & - & - & - & - & - & - \\
\hline Cer_t & 15 & 108 & 21 & 886 & - & - & - & - & - & - & - & - & - & - & - & - & - & - & - & - & - & - & - & - & - \\
\hline Cam_s & 3 & 5 & 3 & 12 & - & - & - & - & - & - & - & - & - & - & - & - & - & - & - & - & - & - & - & - & - \\
\hline Buta & 19 & 8 & 34 & 47 & - & - & - & - & - & - & - & - & - & - & - & - & - & - & - & - & - & - & - & - & - \\
\hline$O s b \_o$ & - & 14 & 0 & 118 & - & - & - & - & - & - & - & - & - & - & - & - & - & - & - & - & - & - & - & - & - \\
\hline Aeg_c & - & - & - & - & - & - & - & + & + & - & - & - & - & - & - & - & + & - & - & - & - & - & - & - & - \\
\hline
\end{tabular}


Tabel 5. Keaneka-ragaman, Nilai Penting (NP) dan Kerapatan (tegakan $/ \mathrm{m}^{2}$ ) mangrove pada jalur transek dan pengamatan bebas di Pulau Nusalaut tahun 2009 (lihat Tabel 3 untuk kode species)

Table 5. Diversity, Important Value (IV), and Density (trees $/ \mathrm{m}^{2}$ ) of mangrove in the transect and free observations in the Nusalaut Island in 2009 (see Table 3 for species code)

\begin{tabular}{|c|c|c|c|c|c|c|c|c|c|c|c|c|c|c|}
\hline \multirow{2}{*}{$\begin{array}{l}S \\
t \\
n\end{array}$} & \multirow{2}{*}{$\begin{array}{l}\text { Village Name \& } \\
\text { Mangrove } \\
\text { parameter }\end{array}$} & \multicolumn{13}{|c|}{ Mangrove species code } \\
\hline & & $\begin{array}{c}\text { Son } \\
-^{a}\end{array}$ & $\begin{array}{l}\text { Son } \\
-{ }^{C}\end{array}$ & $\begin{array}{c}\text { Rhi } \\
\text { _a }\end{array}$ & $\begin{array}{c}\text { Rhi } \\
-s\end{array}$ & $\begin{array}{r}\text { Bru } \\
-g\end{array}$ & $\begin{array}{c}\text { Avi } \\
0\end{array}$ & $\mathrm{Cer}_{-}$ & $\begin{array}{c}\mathrm{Aeg}_{-} \\
\mathrm{C}\end{array}$ & $\begin{array}{c}\text { Aeg } \\
-f\end{array}$ & $\begin{array}{l}\text { His } \\
-{ }^{t}\end{array}$ & $\begin{array}{r}X C l \\
g\end{array}$ & $\begin{array}{r}X c l \\
-m\end{array}$ & $\begin{array}{c}\text { Acr } \\
-{ }^{a}\end{array}$ \\
\hline 1. & $\begin{array}{l}\text { Titawaai-1 } \\
\text { IV Tree } \\
\text { IV Seed } \\
\text { Tree density } \\
\text { Seed density } \\
\sum \text { Spesies } \\
\end{array}$ & $\begin{array}{c}270 \\
129 \\
255 \\
436 \\
7 \\
\end{array}$ & + & $\begin{array}{c}30 \\
136 \\
27 \\
618\end{array}$ & - & - & - & - & $\begin{array}{c}- \\
35 \\
- \\
182\end{array}$ & - & + & - & + & + \\
\hline 2. & $\begin{array}{l}\text { Titawaai-2 } \\
\text { IV Tree } \\
\text { IV Seed } \\
\text { Tree density } \\
\text { Seed density } \\
\text { ESpesies }\end{array}$ & $\begin{array}{l}177 \\
108 \\
150 \\
440 \\
7\end{array}$ & + & $\begin{array}{c}81 \\
192 \\
100 \\
240\end{array}$ & - & - & - & - & + & - & $\begin{array}{c}41 \\
- \\
40 \\
-\end{array}$ & - & + & + \\
\hline 3. & $\begin{array}{l}\text { Sila/Leinitu } \\
\text { IV Tree } \\
\text { IV Seed } \\
\text { Tree density } \\
\text { Seed density } \\
\sum \text { Spesies }\end{array}$ & $\begin{array}{l}178 \\
- \\
220 \\
- \\
12\end{array}$ & + & $\begin{array}{r}30 \\
168 \\
40 \\
960\end{array}$ & + & $\begin{array}{l}92 \\
- \\
80 \\
-\end{array}$ & + & $\begin{array}{l}- \\
22 \\
- \\
80\end{array}$ & $\begin{array}{c}- \\
56 \\
- \\
32\end{array}$ & $\begin{array}{c}- \\
54 \\
- \\
400\end{array}$ & + & - & + & + \\
\hline $\begin{array}{l}4 . \\
.\end{array}$ & $\begin{array}{l}\text { Nalahia } \\
\text { IV Tree } \\
\text { IV Seed } \\
\text { Tree density } \\
\text { Seed density } \\
\sum \text { Spesies }\end{array}$ & $\begin{array}{c}233 \\
64 \\
220 \\
240 \\
7\end{array}$ & + & $\begin{array}{c}- \\
236 \\
- \\
1040\end{array}$ & - & - & $\begin{array}{c}66 \\
- \\
80 \\
-\end{array}$ & - & + & - & + & - & - & + \\
\hline 5. & $\begin{array}{l}\text { Ameth } \\
\text { IV Tree } \\
\text { IV Seed } \\
\text { Tree density } \\
\text { Seed density } \\
\sum \text { Spesies }\end{array}$ & $\begin{array}{c}- \\
166 \\
- \\
136 \\
5\end{array}$ & + & $\begin{array}{l}300 \\
174 \\
333 \\
400\end{array}$ & - & - & - & - & - & - & + & - & - & + \\
\hline 6. & $\begin{array}{l}\text { Akoon } \\
\text { IV Tree } \\
\text { IV Seed } \\
\text { Tree density } \\
\text { Seed density } \\
\sum \text { Spesies }\end{array}$ & $\begin{array}{l}239 \\
130 \\
250 \\
570 \\
9\end{array}$ & + & $\begin{array}{c}61 \\
170 \\
80 \\
760\end{array}$ & - & - & - & + & - & + & + & + & + & + \\
\hline 7. & $\begin{array}{l}\text { Abubu } \\
\text { IV Tree } \\
\text { IV seed } \\
\text { Tree density } \\
\text { Seed density } \\
\sum \text { Spesies }\end{array}$ & $\begin{array}{c}300 \\
- \\
380 \\
- \\
\overline{7}\end{array}$ & + & + & - & - & - & - & - & - & + & + & + & - \\
\hline
\end{tabular}

Rem : See mangrove code in Table 3

Mangrove di Pulau Nusalaut juga didominasi oleh S.alba dengan kisaran NP 177$300(\mathrm{NP}=300$ berarti seluruhnya didominasi oleh S.alba) dengan NP rata-rata di tujuh lokasi (Desa Titawai-1 dan -2, Sila/Leinitu, Nalahila, Ameth, Akoon dan Abubu) sebesar 233 untuk kategori pohon, sedangkan untuk belta didominasi oleh $R$. Apiculata dengan kisaran NP 135 - 236 dan nilai NP rata-rata 181 (Tabel 5). Dari tujuh lokasi, hanya Desa Sila/Leinitu memiliki Keanekaragaman jenis mangrove tertinggi, yakni 12 jenis (enam jenis di dalam transek dan enam jenis di luar jalur transek) disusul Desa Ameth dengan 9 jenis (dua jenis di jalur transek dan tujuh jenis di luar garis transek), sedangkan desa lainnya rata-rata ditemukan tujuh jenis mangrove, dan terendah di Desa Ameth (lima jenis).

Dominasi mangrove jenis $S$. Alba untuk kategori pohon dan $R$. Apiculata untuk kategori belta pada 7 lokasi kajian di Pulau Nusalaut menunjukkan kemiripan dengan dominasi S.alba di Teluk Saparua, Pulau Saparua. Hal ini mengindikasikan bahwa mangrove di dua lokasi tumbuh pada rataan terumbu pulau dengan substrat keras. R. Apiculata walaupun 
bisa tumbuh pada substrat keras, namun pada umumnya memiliki pertumbuhan yang kerdil dibandingkan dengan yang tumbuh pada substrat berlumpur (Teluk Tuhaha).

\section{Peta mangrove hasil analisis multi-data dan multi-sensor satelit Landsat}

Gambar 3 menunjukkan tujuh peta multitemporal mangrove lima tahunan (1985 hingga 2015) yang dihasilkan dari analisis data citra satelit Landsat multi-sensor berdasarkan klasifikasi terbimbing, dengan menerapkan metode Maximum Likelihood. Metode ini memberikan hasil klasifikasi habitat yang baik (Ahman and Quegan, 2012). Pada kajian ini, dihasilkan enam kelas habitat, yaitu laut (putih), rataan terumbu (biru muda dan gelap), daratan (lahan dan vegetasi darat) (abu-abu), serta mangrove (merah), awan (kuning) dan bayangannya (hitam).

Hasil uji keakurasian peta mangrove (Gambar 3) berdasarkan 30 titik pengukuran GPS (Tabel 6) yang terdiri: akurasi produser (Producer Accuracy, PA), yaitu besarnya peluang referensi mangrove bisa dikelaskan dengan benar, atau seberapa baik mangrove di lapangan bisa dipetakan; Akurasi Pengguna (User Accuracy, UA), yakni peluang satu pixel pada peta mewakili dengan benar kelas mangrove di lapangan, atau berapa kuat kelas mangrove di peta dapat dipercaya; serta akurasi keseluruhan (overall acuracy, OA) yang merupakan dasar pengukuran akurasi yang dihitung dengan membagi titik sampel yang benar pada diagonal utama matrik konfusi terhadap jumlah titik observasi (Banko 1998).

Analisis keakurasian dari tujuh peta mangrove multi-temporal (Gambar 3) menunjukkan bahwa PA berkisar antara 57,1$85,7 \%$, UA $92-95,8 \%$ dan OA $56,1-80 \%$. Kecuali UA, nilai PA dan OA peta mangrove tahun 1995 dan 2015 yang masing-masing dihasilkan dari sensor OLI (Landsat-8) dan TM (Landsat-5) relatif lebih rendah dibandingkan hasil penelitian dari berbagai lokasi lain (Tabel 7), namun akurasi tersebut masih cukup berimbang. Berdasarkan peta pada Gambar 3, luas mangrove di Kepulauan Lease dapat dihitung (Tabel 8). Kisaran luas mangrove terendah dan tertinggi di Pulau Saparua adalah 414,1 (1985) dan 468,8 ha (2010); Nusalaut 106,0 (2015) dan 138,2 ha (2005); Haruku 11,8 (1996) dan 18,6 ha (2010), dengan kisaran total mangrove terendah dan tertinggi, yaitu 541,5 (1985) dan 620,5 ha (2010)

Tabel 6. Akurasi (\%) peta mangrove

Table 6. Accuracy (\%) of mangrove maps.

\begin{tabular}{clcccc}
\hline Satelit & Sensor & Tahun & PA & UA & OA \\
\hline L-5 & MSS & 1985 & 78.6 & 95.7 & 73.3 \\
L-5 & TM & 1990 & 82.1 & 95.8 & 76.7 \\
L-5 & TM & 1995 & 60.7 & 94.1 & 56.7 \\
L-7 & ETM+ & 2000 & 82.1 & 92.0 & 76.7 \\
L-5 & TM & 2005 & 71.4 & 95.2 & 66.7 \\
L-5 & TM & 2010 & 85.7 & 96.0 & 80.0 \\
L-8 & OLI & 2015 & 57.1 & 94.1 & 56.1 \\
\hline
\end{tabular}


Wouthuyzen \& Ahmad
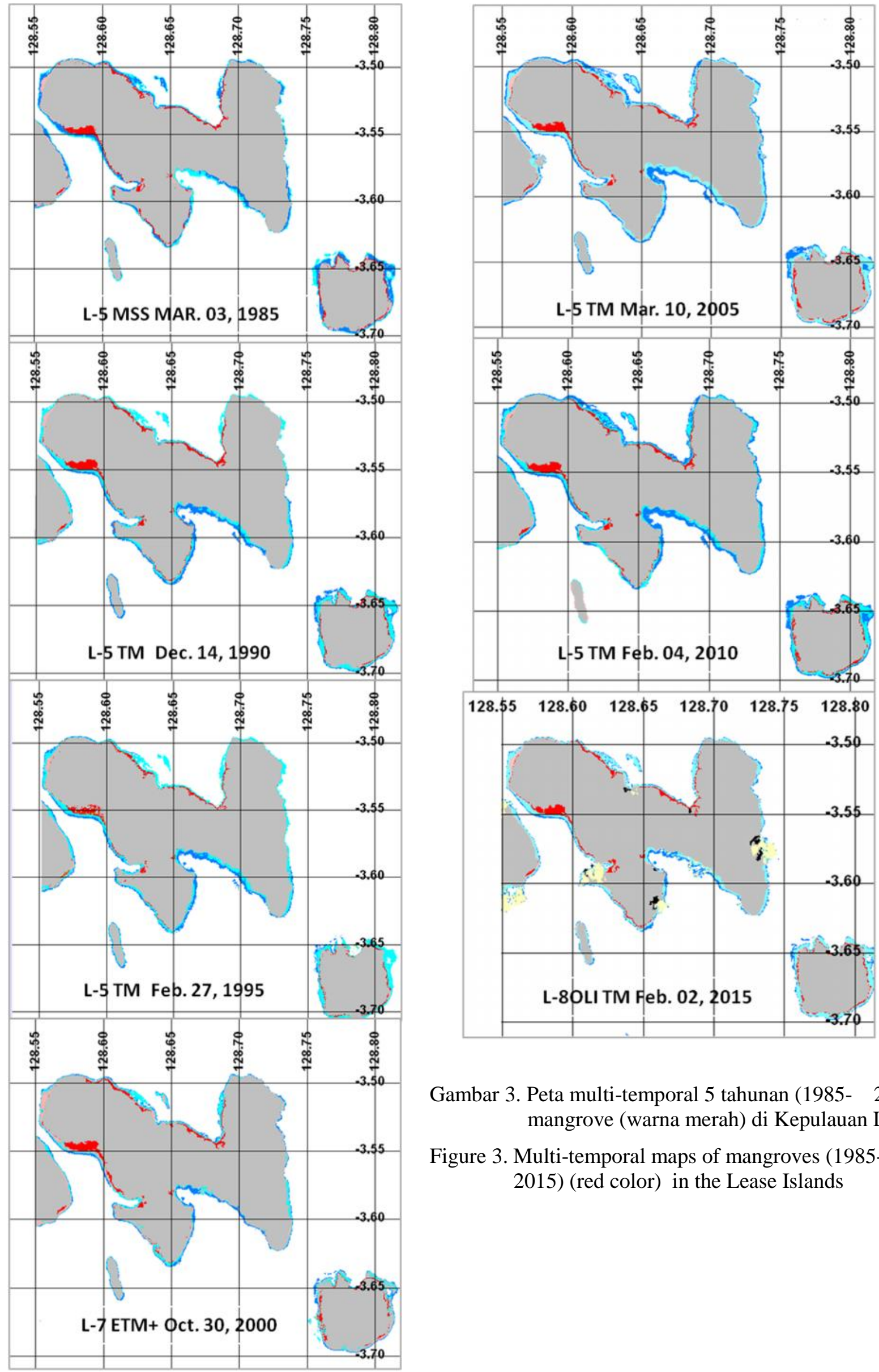

Gambar 3. Peta multi-temporal 5 tahunan (1985- 2015) mangrove (warna merah) di Kepulauan Lease.

Figure 3. Multi-temporal maps of mangroves (19852015) (red color) in the Lease Islands 
Tabel 7. Keakurasian peta mangrove menggunakan berbagai sensor satelit dan analisis dari berbagai lokasi.

Table 7. Accuracies of mangrove maps using various multi-temporal sensors and analysis from many locations.

\begin{tabular}{|c|c|c|c|c|c|c|}
\hline Locaton & Year & $\begin{array}{l}\text { Sensors/ } \\
\text { Satellites }\end{array}$ & $\begin{array}{l}\text { PA } \\
(\%)\end{array}$ & $\begin{array}{l}\mathrm{UA} \\
(\%)\end{array}$ & $\begin{array}{l}\mathrm{OA} \\
(\%)\end{array}$ & Analysis and Sources \\
\hline $\begin{array}{l}\text { Lease,Islands, } \\
\text { Indonesia }\end{array}$ & $\begin{array}{l}1985- \\
2015\end{array}$ & $\begin{array}{l}\text { MSS, TM, } \\
\text { ETM+, OLI }\end{array}$ & $\begin{array}{l}57,1- \\
85,7\end{array}$ & $\begin{array}{l}92,0- \\
95,8\end{array}$ & $\begin{array}{l}56,1- \\
80,0\end{array}$ & $\begin{array}{l}\text { Maximum Likelihood } \\
\text { Classification (MLC), This study }\end{array}$ \\
\hline $\begin{array}{l}\text { Philippines ( } 8 \\
\text { Provinces) }\end{array}$ & 2013 & OLI & $\begin{array}{l}64.9- \\
88,8\end{array}$ & $\begin{array}{l}68,9- \\
96,4\end{array}$ & - & MLC ?; Pagkalinawan, 2015 \\
\hline Johor, Malaysia & $\begin{array}{l}1989- \\
2014\end{array}$ & $\begin{array}{l}\text { TM, ETM+, } \\
\text { OLI }\end{array}$ & - & - & $\begin{array}{l}62,0- \\
95,0\end{array}$ & MLC; Kanniah et al., 2015 \\
\hline \multirow{2}{*}{$\begin{array}{l}\text { Bengkalis Island, } \\
\text { Indonesia }\end{array}$} & \multirow[t]{2}{*}{2010} & \multirow{2}{*}{$\begin{array}{l}\text { Mixed TM } \\
\text { and } \\
\text { ALOS } \\
\text { PALSAR }\end{array}$} & 98,2 & 84,2 & 76,8 & MLC; Jhonnerie et al., 2015 \\
\hline & & & 95,4 & 90,4 & 81,1 & $\begin{array}{l}\text { Object Based Image Analysis } \\
\text { (OBIA), Jhonnerie et al., } 2015\end{array}$ \\
\hline Ca Mau, Vietnam & $\begin{array}{l}1993 \\
2013\end{array}$ & $\begin{array}{l}\text { MSS, TM, } \\
\text { ETM+, OLI }\end{array}$ & $\begin{array}{l}95,5 \\
95,9\end{array}$ & $\begin{array}{l}91,5 \\
88,1\end{array}$ & $\begin{array}{l}84,2 \\
82,3\end{array}$ & OBIA; Son et al., 2015. \\
\hline $\begin{array}{l}\text { Trang province, } \\
\text { Thailand }\end{array}$ & $\begin{array}{l}1988 \\
2004\end{array}$ & $\mathrm{TM}$ & - & - & 72,8 & $\begin{array}{l}\text { Supervised MLC; Sudtongkong, } \\
2013\end{array}$ \\
\hline Kenya, Afrika & $\begin{array}{l}1985- \\
2010\end{array}$ & TM & - & - & 87.5 & $\begin{array}{l}\text { Unsupervised MLC; Kirui et al, } \\
2013 \text {. }\end{array}$ \\
\hline $\begin{array}{l}\text { Philippines (66 } \\
\text { Provinces) }\end{array}$ & 2011 & TM & - & 95,0 & 95.6 & $\begin{array}{l}\text { Iso data (unsupervised) MLC } \\
\text { Long and Giri, } 2011\end{array}$ \\
\hline Saparua Island, & 2007 & ETM+ & - & - & 78,0 & MLC: WaasNababan, 2010: \\
\hline Senegal, Afrika & $\begin{array}{l}1986- \\
2006\end{array}$ & XS (SPOT) & 97,5 & - & 85,7 & OBIA, Conchedda, et al., 2008. \\
\hline $\begin{array}{l}\text { Bangladesh \& } \\
\text { India }\end{array}$ & $\begin{array}{l}1977- \\
2000\end{array}$ & $\begin{array}{l}\text { MSS, TM } \\
\text { and ETM+ }\end{array}$ & - & - & $\begin{array}{l}79,0- \\
86,0\end{array}$ & Supervised MLC; Giri et al., 2007 \\
\hline \multirow{2}{*}{$\begin{array}{l}\text { Dan Sui Estuary, } \\
\text { Taiwan }\end{array}$} & \multirow[t]{2}{*}{2009} & TM, & 97,9 & 98,2 & 98.3 & \multirow[b]{2}{*}{ MLC; Lee and Yeh, 2006} \\
\hline & & $\begin{array}{l}\text { XS (SPOT) } \\
\text { QuickBird }\end{array}$ & $\begin{array}{l}98,0 \\
98,7\end{array}$ & $\begin{array}{l}89,2 \\
97,2 \\
\end{array}$ & $\begin{array}{l}97,6 \\
89,3\end{array}$ & \\
\hline Nusalaut Island, & 2005 & ETM+ & - & - & 83,0 & MLC: Kalay, dan Waas. 2005: \\
\hline $\begin{array}{l}\text { Selangor, } \\
\text { Malaysia }\end{array}$ & 2013 & TM & 99,7 & 99,9 & - & MCL. Ahmad and Quegan, 2013 \\
\hline
\end{tabular}

Tabel 8. Luas mangrove (ha) di Kepulauan Lease berdasarkan data citra Landsat.

Table 8. Mangrove areas (ha) in the Lease Islands based on Landsat Satellite data.

\begin{tabular}{clccccc}
\hline Year & Sensor & $\begin{array}{c}\text { Saparua } \\
\text { (ha) }\end{array}$ & $\begin{array}{c}\text { Nusalaut } \\
\text { (ha) }\end{array}$ & $\begin{array}{l}\text { Haruku } \\
\text { (ha) }\end{array}$ & $\begin{array}{l}\text { Total } \\
\text { (ha) }\end{array}$ & $\begin{array}{c}\text { Changes } \\
\text { ha/year }\end{array}$ \\
\hline 1985 & MSS & 414.1 & 115.6 & 11.9 & 541.5 & - \\
1990 & TM & 470.2 & 111.0 & 13.5 & 594.7 & 10.5 \\
1995 & TM & 427.3 & 130.3 & 11.8 & 569.3 & -5.1 \\
2000 & ETM+ & 467.3 & 109.6 & 13.4 & 590.4 & 4.2 \\
2005 & TM & 464.8 & 138.2 & 14.4 & 617.4 & 5.4 \\
2010 & TM & 468.8 & 133.1 & 18.6 & 620.5 & 0.6 \\
2015 & OLI & 444.2 & 106.0 & 13.0 & 563.3 & -11.4 \\
\hline
\end{tabular}




\section{Pembahasan}

Woodroffe (1987) mengamati pengaturan (setting) lingkungan global terhadap perkembangan mangrove di pulaupulau di Samudra Pasifik (Tabel 9). Pengaturan lingkungan ini mewakili kombinasi proses geomorfologi tertentu yang dominan di suatu lokasi yang kemudian akan berpengaruh pada keterbatasan ekologi dan dinamika populasi jenis mangrove di lokasi tersebut. Menurutnya, ada empat pengaturan lingkungan mangrove di pulau-pulau di Pasifik: Pengaturan-1, sungai yang mendepositkan sedimen yang terbangun dari bahan material terkikis berasal dari daratan yang berjarak jauh. Pengaturan ini ditandai oleh mangrove yang tumbuh di delta/estuari/daerah yang dipengaruhi pasangsurut mikro (micro tidal); Pengaturan-2, cekungan berisi deposit batuan dasar/lapisan tanah keras yang membentuk teluk/daerah terlindung. Pengaturan ini ditandai mangrove yang tumbuh pada cekungan deposit tersebut; Pengaturan-3, rataan terumbu yang berkaitan dengan deposit karbonat. Pengaturan ini ditandai mangrove yang tumbuh di rataan terumbu yang terlindung oleh beting karang. Pengaturan- 4 adalah pengaturan yang berbeda dari ketiga lainnya. Pengaturan ini ditandai mangove yang tumbuh pada bagian yang rendah di darat.

Tabel 9. Sebaran genera dan jumlah species mangrove yang tumbuh pada pulau-pulau karang di Pasifik Woodroffe (1987) dan perairan Indonesia.

Table 9. Distribution of genera and species number of true mangrove grow at coral islands on the Pacific Woodroffe (1987) and Indonesian waters..

\begin{tabular}{|c|c|c|c|c|c|c|c|c|c|c|c|c|c|c|}
\hline \multirow{2}{*}{ Locations } & \multicolumn{14}{|c|}{ Genera and species numbers of true mangroves } \\
\hline & Rhi & $\mathrm{Bru}$ & $\mathrm{Cer}$ & $A v i$ & Aeg & $X y l$ & Lum & Cam & Aegi & $O s b$ & Son & Scy. & Nyp & Total \\
\hline \multicolumn{15}{|l|}{ Pacific } \\
\hline $\begin{array}{l}\text { New Guinea } \\
\text { (PNG ) }\end{array}$ & 4 & 6 & 2 & 5 & 1 & 3 & 2 & 1 & 1 & 1 & 3 & & 1 & 30 \\
\hline $\begin{array}{l}\text { Solomon } \\
\text { Islands }\end{array}$ & 4 & 3 & 1 & 3 & 1 & 1 & 1 & & & 1 & 2 & 1 & 1 & 19 \\
\hline Vanuatu & 3 & 2 & 1 & 1 & & 1 & 1 & & & & 2 & & & 11 \\
\hline New Caledonia & 5 & 1 & 1 & 1 & & & 2 & & & & 1 & & & 11 \\
\hline Fiji & 3 & 1 & & & & 2 & 1 & & & & & & & 7 \\
\hline Tonga & 3 & 1 & & & & 2 & 1 & & & & & & & 7 \\
\hline Samoa & 2 & 1 & & & & 1 & & & & & & & & 4 \\
\hline Tuvalu & 1 & & & & & & 1 & & & & & & & 2 \\
\hline Kiribati & 1 & 1 & & & & & 1 & & & & 1 & & & 4 \\
\hline Nauru & & 1 & & & & & & & & & & & & 1 \\
\hline Palau and Yap & 2 & 1 & 1 & 1 & & 1 & 1 & & & & 1 & 1 & 1 & 10 \\
\hline Guam & 2 & 1 & & 1 & & 1 & 1 & & & & & & 1 & 7 \\
\hline Saipan & & 1 & & & & & 1 & & & & & & & 2 \\
\hline $\begin{array}{l}\text { Truk, Ponape } \\
\text { and Kusaie }\end{array}$ & 2 & 1 & & & & 1 & 1 & & & & 1 & & 1 & 7 \\
\hline Marshall Island & 1 & 1 & & & & & 1 & & & & 1 & & & 4 \\
\hline New Zwealand & & & & 1 & & & & & & & & & & 1 \\
\hline \multicolumn{15}{|l|}{ Indonesia } \\
\hline $\begin{array}{l}\text { Tuhaha Bay, } \\
\text { Saparua Island } \\
\text { (this study) }\end{array}$ & 3 & 2 & 2 & & 2 & 1 & 1 & 1 & & & 2 & & 1 & 15 \\
\hline $\begin{array}{l}\text { Saparua Island } \\
\text { (this study) }\end{array}$ & 2 & & & & 1 & & & & & & 2 & & & 5 \\
\hline $\begin{array}{l}\text { Nusalaut Island } \\
\text { (this study) }\end{array}$ & 1 & 1 & 1 & & 2 & 1 & & & & & 2 & & & 8 \\
\hline $\begin{array}{l}\text { Derawan, and } \\
\text { Wakatobi } \\
\text { Islands }{ }^{1)}\end{array}$ & 2 & 1 & & & & & & & & & & & & 3 \\
\hline $\begin{array}{l}\text { Hoga, } \\
\text { Wakatobi } \\
\text { Islands } 1)\end{array}$ & 2 & 1 & 2 & & & & & & & 1 & 2 & & & 8 \\
\hline $\begin{array}{l}\text { Kalaedupa, } \\
\text { Wakatobi } \\
\text { Islands }{ }^{1)}\end{array}$ & 2 & 1 & 2 & 1 & 1 & 2 & 1 & & & & 2 & & 1 & 13 \\
\hline $\begin{array}{l}\text { Nyamuk, } \\
\text { Karimun Jawa } \\
\text { Islands } 2 \text { ) }\end{array}$ & 2 & 2 & 1 & 1 & & 2 & 1 & & & & & & & 9 \\
\hline
\end{tabular}


Tabel 9. Lanjutan

Table 9. Continuous

\begin{tabular}{|c|c|c|c|c|c|c|c|c|c|c|c|c|c|c|}
\hline \multirow{2}{*}{ Locations } & \multicolumn{14}{|c|}{ Genera and species numbers of true mangroves } \\
\hline & $R h i$ & Bru & $\mathrm{Cer}$ & $A v i$ & Aeg & $X y l$ & Lum & Cam & Aegi & $O s b$ & Son & Scy. & Nyp & Total \\
\hline $\begin{array}{l}\text { Padaido } \\
\text { Islands, Papua }\end{array}$ & 2 & 2 & 1 & 1 & & & 1 & & & & 1 & & & 8 \\
\hline $\begin{array}{l}\text { Biak Island, } \\
\text { Papua 3) }\end{array}$ & 2 & 2 & 2 & & & 2 & 1 & 1 & & 1 & 1 & & & 11 \\
\hline $\begin{array}{l}\text { Biak Island, } \\
\text { Papua } 4)\end{array}$ & 2 & 2 & & & 1 & & 1 & & & & 1 & & 1 & 8 \\
\hline $\begin{array}{l}\text { Numfor Island, } \\
\text { Papua }{ }^{5} \text { ) }\end{array}$ & 3 & 3 & 1 & 1 & & 3 & & 1 & & 1 & & & 1 & 14 \\
\hline $\begin{array}{l}\text { Abasiaidi } \\
\text { Village, } \\
\text { Supiori, Papua }\end{array}$ & 2 & 3 & & & & 1 & & & & & 2 & & & 8 \\
\hline $\begin{array}{l}\text { Pari, Seribu } \\
\text { Island 6) }\end{array}$ & 3 & 2 & & 1 & & 1 & & & & & 1 & & 1 & 9 \\
\hline $\begin{array}{l}\text { Sempu Island, } \\
\text { East Java }{ }^{7)}\end{array}$ & 2 & 2 & 2 & & 1 & & & & & & & & & 7 \\
\hline $\begin{array}{l}\text { Likupang, Norh } \\
\text { Sulawesi }{ }^{8)}\end{array}$ & 1 & 1 & 1 & 1 & & 1 & & & & & 1 & & & 6 \\
\hline $\begin{array}{l}\text { North } \\
\text { Gorontalo 9) }\end{array}$ & 3 & 3 & 2 & 3 & 2 & 1 & & & & & 2 & & & 16 \\
\hline $\begin{array}{l}\text { Eastern Bintan } \\
\text { Island 10) }\end{array}$ & 2 & 1 & & & & 1 & & & & & & & 1 & 5 \\
\hline $\begin{array}{l}\text { Frequency } \\
\text { occurrences } \\
(\%)\end{array}$ & 90 & 90 & 45 & 42 & 29 & 61 & 58 & 6 & 3 & 10 & 61 & 6 & 32 & \\
\hline
\end{tabular}

Remarks: See mangrove Code in Table 3

1) Jamili et al. 2015; 2) Kartijono et al. 2010; 3) Soselisa 2006; 4) Katiandhago 2015;

5) Warpur 2016; 6) Wouthuyzen et al.; 7) Sulistiyowati 2009; 8) Suzana et al. 2011; 9). Kasim et al. 2017; and 10) BAPEDA Kab. Bintan 2010

Berdasarkan empat skenario Pengaturan lingkungan, tampak bahwa keanekaragaman jenis mangrove tinggi (10-30 jenis), seperti di pulau-pulau di Samudra Pasifik (PNG, Pulau Solomon, Vanuatu, New Caledonia, Palau/Yap), maupun pulau-pulau di perairan Indonesia, seperti Pulau Saparua, Kalaedupa, Biak dan Numfor (Papua) dan Gorontalo Utara berada di bawah pengaruh Pengaturan-1 dan/atau Pengaturan-2 (Tabel 9). Sebaliknya, pulau-pulau dengan keanekaragaman jenis mangrove $<10$ jenis berada di bawah pengaruh Pengaturan-3 dan/atau Pengaturan-4, yaitu mangrove yang tumbuh di atas rataan terumbu karang atau pada lokasilokasi rendah di daratan. Ditinjau dari frekuensi kehadiran berbagai jenis mangrove, dapat diketahui bahwa Rhizophora spp dan Bruguiera spp memiliki nilai kehadiran tertinggi (90\%), disusul Xylocarpus spp dan Sonneratia sp (61\%), dan Lumnitzera sp (58\%), sedangkan jenis lainnya memiliki kehadiran < 50\% (Tabel 9). Jadi, Rhizophora spp dan Bruguiera spp. merupakan jenis mangrove yang mendominasi semua pengaturan lingkungan (Pengaturan-1 -4) untuk mangrove yang tumbuh di pulau-pulau yang relatif kecil, namun kajian ini belum menampakan pemisahan jenis mangrove yang jelas/spesifik untuk setiap pengaturan lingkungan.

Mangrove di Teluk Tuhaha tampaknya berada di bawah pengaruh Pengaturan-1, karena mangrove tumbuh di sekitar sungai berukuran sedang (Wai Ila) dan alur-alur air tawar (creek) yang merupakan daerah estuari, dengan keanekaragaman serta nilai penting (NP) tinggi untuk Rhizophora $(\mathrm{NP}=169)$; disusul Sonneratia $(\mathrm{NP}=86)$ dan pohon tinggi (Gambar 4). Sebaliknya, mangrove di Teluk Saparua dan Pulau Nusalaut lebih dominan berada di bawah pengaruh Pengaturan-3. Mangrove di Teluk Saparua tumbuh pada rataan terumbu dengan keanekaragaman jenis yang rendah dan lebih didominasi oleh jenis Sonneratia sp yang ditemukan di seluruh stasiun pengamatan (21 stasiun) dengan kehadiran $100 \%$ (Tabel 4), sedangkan Rhizophora sp hadir hanya di 7 stasiun (33\%), dan Aegiceras $s p$ hadir terendah di 3 stasiun $(14 \%)$. 
Mangrove kategori pohon di Pulau Nusalaut juga didominasi Sonneratia $s p$ yang hadir di lima desa dari enam desa yang diamati (89\%) dengan NP berkisar 177 - 300. NP 300 terdapat di Desa Abubu yang berarti bahwa hanya ada satu jenis mangrove disana, yakni Sonneratia. Disisi lain, Desa Ameth juga memiliki NP $=300$ untuk jenis Rhizophora, namun kehadirannya hanya $17 \%$, dan tumbuhnya juga kerdil (Gambar 4). Pada Pengaturan-4, mangrove jenis Bruguiera dan Lumnitzera sering dijumpai tumbuh di darat pada cekungan-cekungan dengan dasar karang, namun memiliki sedimen berupa lumpur/pasir yang kaya akan bahan organik (Woodroffe 1987).
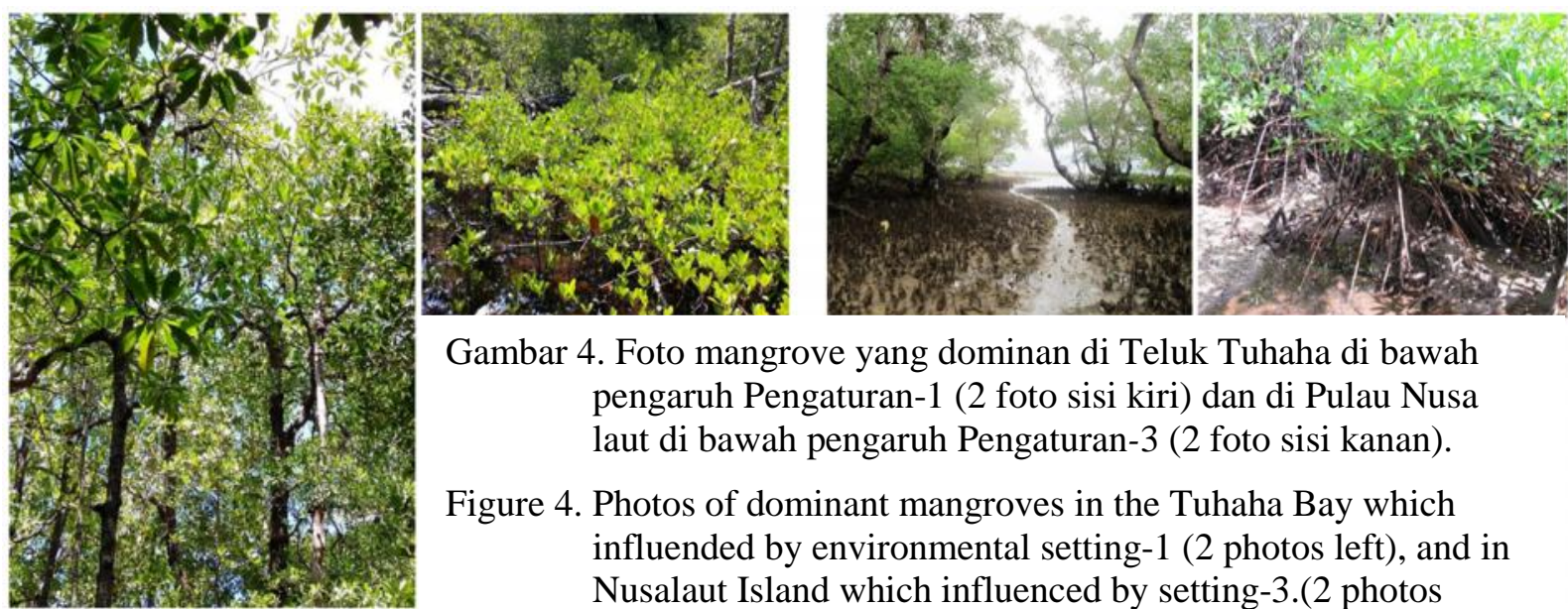

Gambar 4. Foto mangrove yang dominan di Teluk Tuhaha di bawah pengaruh Pengaturan-1 (2 foto sisi kiri) dan di Pulau Nusa laut di bawah pengaruh Pengaturan-3 (2 foto sisi kanan).

Figure 4. Photos of dominant mangroves in the Tuhaha Bay which influended by environmental setting-1 ( 2 photos left), and in Nusalaut Island which influenced by setting-3.(2 photos

Hasil pemetaan mangrove menggunakan sensor ETM+ oleh Waas dan Nababan (2010) diperoleh luas 572 ha hanya untuk Pulau Saparua saja. Hal ini menunjukkan adanya perbedaan yang cukup besar dengan hasil kajian ini (Tabel 8), karena adanya/terpetakannya sebaran mangrove di sisi barat Teluk Saparua, sedangkan pada kajian ini tidak terditeksi adanya sebaran mangrove lebat di lokasi tersebut, melaikan hanya spot-spot kecil saja.

Luas mangrove (Tabel 8) di setiap pulau berfluktuasi dari waktu ke waktu yang menunjukkan adanya perubahan luas, baik bertambah atau berkurang. Secara total, luas mangrove di Kepulauan Lease meningkat dari tahun 1985 ke tahun 1990 seluas 53,2 ha $(10,5 \%)$, namun turun seluas 25,4 ha $(-5,1 \%)$ pada tahun 1995. Luas mangrove meningkat kembali 21,1 ha $(4,2 \%)$ di tahun 2000 dan 27,0 ha $(5,6 \%)$ di tahun 2005 , serta 3,1 ha $(0,6 \%)$ pada tahun 2010 , namun turun seluas 57,2 ha ($11,4 \%$ ) pada tahun 2015.

Fluktuasi luas mangrove, baik ke arah bertambah atau berkurang dari tahun 1985 hingga 2015 tidak lebih dari 12\%. Hal ini menunjukkan bahwa fluktuasi luas tersebut kemungkinan besar bukan karena pemanfaatan mangrove yang berlebih atau karena dikonversi menjadi lahan lain (tambak), seperti di pantai utara Jawa Barat (Wouthuyzen et al. 2014).
Mangrove di Kepulauan Lease, lebih aman dan terkelola dengan baik karena adanya kearifan lokal berupa "Kewang", yaitu pengawas hutan (Kewang darat/laut untuk menjaga mangrove) di hampir semua desa kajian yang ditunjuk oleh kepala desa atau ketua adat desa. Jadi, fluktuasi luas mangrove pada Tabel 8 diduga karena adanya ganguan awan/ haze seperti pada citra Landsat-8 OLI (2015), sehingga menghasilkan sedikit bias dalam analisa citra. Di samping itu, walaupun seluruh citra yang dipakai telah terkoreksi dari pengaruh geometrik, atmosferik dan radiometrik, namun klasifikasi terbimbing dengan menggunakan metode maximum likelihood belum dapat memberikan hasil maximal, namun cukup realistis untuk memetakan mangrove. Metode klasifikasi OBIA (Object Based Image Analysis) pada Tabel 7 tampaknya perlu dicoba guna mendapatkan peta mangrove dengan tingkat keakurasian yang lebih tinggi.

Dari peta multi-temporal citra satelit, mangrove di Pulau Saparua menyebar di Teluk Tuhaha sepanjang kurang-lebih 17,6 km dimulai dari Desa Ihamahu hingga ke wilayah petuanan Desa Porto utara yang merupakan sebaran mangrove terpanjang di Pulau ini, sedangkan sebaran mangrove di Desa Haria (Teluk Haria) dan Tiouw (Teluk Saparua) sangat terbatas masing-masing sepanjang 1,2 dan $0,9 \mathrm{~km}$ saja. Mangrove lebat lainnya 
tersebar di petuanan Desa Porto bagian selatan hingga ke bagian utara Teluk Haria sepanjang $5,8 \mathrm{~km}$ (Gambar1). Di Pulau Nusalaut, mangrove menyebar di sepanjang garis pantai pada desa-desa tertentu saja, yaitu Desa Sila, Nalahia, Ameth, Akoon, Abubu dan Desa Titawaai dengan panjang mangrove rata-rata sekitar $1 \mathrm{~km}$ (Gambar 1). Pulau kecil (Pulau Maulana) terdapat beberapa tegakan mangrove yang hanya berupa spot kecil, sehingga keberadaan mangrove tidak nyata atau dapat diabaikan. Di Pulau Haruku, mangrove yang dikaji hanya di sisi bagian tenggara saja yang sebarannya berada di petuanan Desa Aboru, dengan panjang mangrove sekitar $1,1 \mathrm{~km}$ (Gambar 1). Mangrove yang lebih luas sebenarnya berada di sisi barat, yaitu pada lintasan Landsat Path 109 \& Row 063, di luar jangkauan kajian ini yang hanya membahas area yang terletak pada Path 108 \& Row 063 (Tabel 2). Oleh karena itu, kajian ini belum membahas tuntas seluruh luas mangrove yang ada di Kepulauan Lease. Jadi ke depan, mangrove di sisi barat Pulau Haruku (Path 109 \& Row 063) perlu dipetakan, sehingga kondisi mangrove di seluruh Kepulauan Lease dapat diketahui

Walaupun sebaran panjang mangrove, khususnya Di Pulau Saparua dapat mencapai $17,6 \mathrm{~km}$, namun lebar rata-rata mangrove di seluruh Kepulauan Lease memperlihatkan hanya berkisar 30-350 $\mathrm{m}$ dari garis pantai, kecuali di wilayah petuanan Desa Porto bagian selatan $( \pm 850 \mathrm{~m})$. Oleh karena itu, mangrove di Kepulauan Lease perlu dipertahankan sebagai jalur hijau (green belt) yang berdasarkan konsep Wartaputra (1990) bahwa jalur hijau = 130 x rata-rata tunggangan air pasang. Jika tinggi pasang di Kepulauan Lease sekitar $2 \mathrm{~m}$, maka jalur hijau adalah $260 \mathrm{~m}$, sehingga sebagian besar mangrove di Kepulauan Lease harus dijadikan jalur hijau. Jalur hijau mangrove dapat menahan gempuran ombak besar dari Laut Banda pada musim tertentu, disamping itu dapat mencegah proses sedimentasi dari darat, sehingga ekosistem di depan mangrove, yaitu lamun dan terumbu karang mendapat keuntungan pula dari adanya jalur hijau mangrove.

Tingginya akurasi pemetaan mangrove di lokasi lain, di luar kajian ini (Tabel 7), karena digunakannya banyak data uji lapangan (ground truth) hingga 322 titik sampling acak seperti di Senegal (Conchedda et al., 2008); atau 447 titik di Pulau Bengkalis, Indonesia
(Jhonnerie et al. 2015) dan bahkan hingga 2000 titik di $\mathrm{Cu}$ Mau, Vietnam (Son et al. 2015). Metoda klasifikasi yang dipakai adalah Object Based Image Analysis (OBIA) yang tampaknya memberikan akurasi peta lebih tinggi dibandingkan dengan metoda klasifikasi konvensional, yakni Maximum Likelihood, baik secara terbimbing, maupun tidak terbimbing. Pada kajian ini, hanya tersedia 30 titik uji lapangan (23 di Pulau Saparua dan 7 titik di Pulau Nusalaut). Disamping itu, citra Landsat8 OLI (2015) terpengaruh oleh tutupan awan, sedangkan citra Landsat-5 TM tahun 1995 terpengaruh oleh kabut (haze).

Posisi geometri peta dari Landsat- 8 OLI yang dipakai sebagai peta acuan tidak benar-benar tepat tumpang tindih (match) dengan peta mangrove yang dihasilkan memakai sensor MSS, TM dan ETM+, sehingga walaupun sudah dilakukan koreksi geometrik, tingkat kesalahan rata-rata (Root Mean Square error/ RMSE) koordinat peta dari sensor MSS, TM dan ETM+ masih sekitar 0,30,6 pixel $(9-18 \mathrm{~m})$. Hal ini diduga turut meningkatkan ketidak-akurasian peta mangrove yang dihasilkan pada kajian ini.

\section{Kesimpulan}

Mangrove di Kepulauan Lease, Propinsi Maluku telah dipetakan menggunakan kombinasi data lapangan, data multi-temporal dan multi-sensor citra satelit Landsat. Survei lapangan menunjukkan bahwa mangrove di lokasi kajian terbagi atas dua kelompok berdasarkan Pengaturan (Setting) lingkungan. Di Teluk Tuhaha, mangrove dicirikaan dengan tingginya keanekaragaman jenis (15 species) dan didominasi oleh Rhizophora sp ( $\mathrm{NP}=169)$; dan Sonneratia sp $(\mathrm{NP}=86)$, dan berada di bawah pengaruh Pengaturan-1, (mangrove tumbuh di perairan estuari, di sekitar sungai (Wai Ila) dan alur-alur air tawar). Sebaliknya, mangrove di Teluk Saparua dicirikan dengan rendahnya keanekaragaman jenis (lima species) yang $100 \%$ didominasi oleh jenis Sonneratia $s p$, sedangkan di Pulau Nusalaut juga memiliki keanekaragaman jenis rendah (delapan jenis) dan $88 \%$ didominasi oleh Sonneratia sp dengan Nilai Penting (NP) berkisar 177-300. Mangrove di Teluk Saparua dan Pulau Nusa laut berada dibawah pengaruh Pengaturan-3 (mangrove dominan tumbuh di rataan terumbu). Data multi-temporal dan multisensor dari citra satelit Landsat lima tahunan selama 30 tahun (1985-2015) dan data survei 
lapangan pada kajian ini terbukti efektif dan efisien memetakan, memantau dan mengevaluasi mangrove secara multi temporal untuk kepentingan pengelolaan mangrove berkelanjutan di Kepulauan Lease, Provinsi Maluku, tanpa harus turun lagi ke lapangan. Data citra Landsat baik yang tersedia di masa akan datang atau di masa lalu lainnya, secara langsung dapat digunakan untuk membuat peta mangrove baru dengan mengaplikasikan training area serta algoritma klasifikasi terbimbing maksimum likelihood yang telah dikembangkan pada kajian ini. Luas mangrove di Kepulauan Lease walaupun berfluktuasi, namun relatif stabil, karena sebagian besar mangrove terproteksi oleh kearifan lokal (Kewang), dan bukan disebabkan pemanfaatan/konversi mangrove menjadi lahan lain. Lebar mangrove rata-rata di pantai Kepulauan Lease sempit $(<260 \mathrm{~m})$, sehingga seluruh mangrove sebaiknya dijadikan jalur hijau (green belt) untuk melindungi pulaupulau di Kepuluan Lease dari pukulan ombak besar Laut Banda pada musim tertentu, disamping dapat mendukung ekosistem lamun dan terumbu karang pada bagian depan. Ke depan, metoda klasifikasi lain, seperti OBIA perlu dicoba untuk mendapatkan peta mangrove dengan tingkat keakurasian lebih tinggi.

\section{Persantunan}

Terima kasih yang mendalam kami sampaikan kepada sahabat baik kami Sdr. Frits S. Pulumahuny M.Si. dari P2LD LIPI, Ambon yang telah mengijinkan data lapangannya untuk ditulis pada naskah ini beberapa bulan sebelum beliau meninggal dunia. Oleh karena itu, kami penulis sepenuhnya mendedikasikan karya tulisan ilmiah ini kepada beliau sebagai seorang peneliti mangrove yang handal di lapangan. Ucapan sama kami sampaikan kepada Sdr. Abraham Simon Leatemia, Teknisi mangrove P2LD-LIPI, yang telah membantu transek dan mengumpulkan data mangrove di lapangan. Kami mengucapkan terima kasih kepada tiga mitra bestari/pengulas (reviewer), yang telah meluangkan waktunya dalam membaca naskah awal dengan teliti dan memberikan masukan yang sangat berharga sehingga membuat tulisan ini menjadi jauh lebih bagus.

\section{Daftar Pustaka}

Ahmad, A. and S. Quenan. 2012. Analysis of maximum likelihood classification on multi-spectral Data. Applied Mathematical Sciences 6 (129): 6425 - 6436.

BAPEDA Kab. Bintan 2010. Potensi

Ekosistem penting dan kondisi

hidrologinya di wilayah Bintan bagia timur.

BAPPEDA Kabupaten Bintan, Propinsi

Kepulauan Riau. 93 hal.

Burbridge, P.R, and Koesoebiono. 1980. Management of mangrove exploitation in Indonesia: Management of brakish-water forests in Indonesia. Presented at Seminar on Mangrove Ecosystem, 27 February - 1 March 1978, Jakarta.

Banko, G. 1998. A Review of Assessing the Accuracy of Classifications of Remotely Sensed Data and of Methods Including Remote Sensing Data in Forest Inventory.IIASA Interim Report. IR-98081. http:// pure.iiasa.ac.at/5570/ 36 pp.

Chavez, P. S., Jr. 1988. An improved darkobject subtraction technique for atmospheric scattering correction of multi-spectral data. Remote Sens. Environ. 24:459-479.

Chander, G., B.L. Markham, and J.A. Barsi, 2007. Revised Landsat-5 Thematic Mapper Radiometric Calibration. IEEE Geo-science and remote sensing. 4(3):490-484.

Cholik, F. and A. Poernomo. 1986. Development of aquaculture in mangrove areas and its relationship to the mangrove ecosystem. In: Mepham, R.H. 1986. Papers contributed to the workshop on strategies for the management of fisheries and aquaculture in mangrove ecosystems. Bangkok, Thailand, 23 June 1986. p. 93-104.

Conchedda, G., L. Durieux, and P. Maya. 2008. An object-based method for mapping and change analysis inmangrove ecosystems. ISPRS Journal of Photogrammetry \& Remote Sensing 63 (2008): 578-589

Cox, G.W. 1967. Laboratory Manual of General ecology. M.W.C.Brown Company, Mennesota: $165 \mathrm{pp}$.

Darsidi, A. 1984. Mangrove forest management in Indonesia. In: Soemodihardjo, S. et al (eds) Proc.of the Seminar on the mangrove ecosystem II, Baturaden, 1982. LIPI: 19-26.

FAO. 2007. The world's mangrove 1980-2005. FAO forestry paper 153 , Rome, Italy.

Giesen, W. 1993. Indonesia's mangroves: an update on remaining area and main management issues. Presented at the international seminar on coastal zone 
management of small island ecosystems. Ambon 7 - 10 April 1993. AWB Indonesia. $10 \mathrm{pp}$.

Giesen W., S. Wulfrant, M. Sieren, and I. Scholten. 2006. Mangrove Guide Book for Southeast Asia. Bangkok: FAO and Wet Land International.

Gilmore, S., A. Saleem, and A. Dewan, 2015. Effectiveness of DOS (Dark-Object Subtraction) method and water index techniques to map wetlands in a rapidly urbanising megacity with Landsat 8 data. Proceedings of Re-search@Locate, the academic re-search stream at Locatein conjunction with the annual conference on spatial information in Australia and New Zealand (Locate 2015).

Giri, C., B. Pengra, Z. Zhu, A. Singh, and L.L. Tiesze. 2007. Monitoring mangrove forest dynamics of the Sundarbans in Bangladesh and India using multi-temporal satellite data from 1973 to 2000. Estuarine, Coastal and Shelf Science 73: 91-100.

Hartini, S., G.B. Saputro, and M.Y. Suprajaka. 2010. Assessing the use of remote sensed data for mapping mangrove Indonesia.Selected Topics in Power System and Remote Sensing. In $6^{\text {th }}$ WSEAS International Converence on Remote Sensing (REMOTE 10). Iwate Prefectural University, Japan, October 4-6, 2010:210215.

Hutomo, M and M.K. Moosa. 2005. Indonesian Marine and coastal biodiversity: Present Status. Indian Journal of Marine Science 34(1):88-97.

Jamili, A. Sani, R. Djalante, and Y.B Pasolon. 2015. Mangrove Composition and Structure at Small Islands in Wakatobi National Park, Southeast Sulawesi. Proceedings of the 13th International Conference on Environment, Ecosystems and Development (EED '15). Kuala Lumpur, Malaysia, April 23-25, 2015. Pp. 168-178.

Jhonnerie, R., V.P. Siregar, B. Nababan, L.B. Prasetyod, and S.Wouthuyzen. 2015. Random forest classification for mangrove land cover mapping using Landsat $5 \mathrm{TM}$ and ALOS PALSAR imageries. Procedia Environmental Sciences. $24: 215$ - 221

Kalay, D.E. and H.J.D.Waas. 2005. Aplikasi Data Citra Satelit Landsat 7/ETM+ untuk Menentukan Kerapatan Vegetasi Bakau di Pulau Nusalaut, Maluku Tengah. Triton.
Jurnal Manajemen Sumberdaya Perairan 3(1):33-40.

Kanniah, K.D., A. Sheikhi, A.P. Cracknell, H.C. Goh, K.P. Tan, C. S. Ho and F.N. Rasli, 2015. Satellite Images for Monitoring Mangrove Cover Changes in a Fast Growing Economic Region in Southern Peninsular Malaysia. Remote Sens. 7: 14360-14385. doi:10.3390/ rs71114360

Kasim, F., S. Nursinar, C. Panigoro, Z. Karim, Z. and A. Lamalango, 2017. True mangrove of North Gorontalo Regency, Indonesia, their list, status and habitat-structural complexity in easternmost coast area. AACL Bioflux 10(6):1445-1455.

Kartijono, N.D., Rahayuningsih, M., dan Abdullah, M. 2010. Keanekaragaman Jenis Vegetasi dan Profil Habitat Burung di Hutan Mangrove Pulau Nyamuk Taman Nasional Karimunjawa. Biosaintifika 2(1):27-39.

Katiandhago, B. 2015. Analisis struktur dan status ekosistem mangrove di perairan timur Kabupaten Bisk Numfor. Jurnal Ilmiah agribisnis dan Perikanan (agrikan UMMUTernate).8(1):8-12.

Kirui, K.B., J.G. Kairo, J. Bosire, K.M. Viergever, S. Rudra, M. Huxham, and R.A. Briers. 2013. Mapping of mangrove forest land cover change along the Kenya coastline using Landsat imagery. Ocean \& Coastal Management 83: 19-24

Kitamura, S., C. Anwar, A. Chaniago, and S. Baba. 1997. Handbook of mangroves in Indonesia - Bali \& Lombok - JICA, ISME, Japan, p.119.

Lee, T.M. and H.C. Yeh. 2009. Applying remote sensing techniques to monitor shifting wetland vegetation: A case study of Danshui River estuary mangrove communities, Taiwan. Ecological Engineering 35: 487-496.

Long, J.B. and C. Giri. 2011. Mapping the Philippines' Mangrove Forests Using Landsat Imagery. Sensors 11:2972-2981. doi:10.3390/ s110302972

Pagkalinawan, E.H., 2015. Mangrove Forest mapping Using Landsat 8 Images. Mangrove proceedings V7. indd 60. $6 / 10 / 2015$.

Pramudji, 2008. Mangrove di Indonesia dan Upaya Pengelolaannya Orasi pengukuhan Professor Riset, Bidang Ilmu Biologi Laut LIPI. Tidak dipublikasi, $53 \mathrm{pp}$.

Sapulete, D. Soetomo, S. Prawiroatmodjo dan A. Budiman, 1986. Struktur dan Komposisi 
Tumbuhan Hutan Mangrove di sekitar Sorong Irian Jaya. Prosiding Seminar Ekosistem Mangrove III, Denpasar Bali, 5 8 Agustus 1986. Panitia Nasional Program MAB LIPI Jakarta hal.80-85.

Snedaker, S.C. 1984. The Mangroves of Asia and Oceania: Status and Research Planning. In: proceedings of the Asian Symposium on Mangrove Environment Research and Management, p 5-15 Kuala Lumpur, August 25-29, 1980. Edited by E. Soepadmo, A.N. Rao and D.J. MacIntosh. 1984

Soemodihardjo, S., P. Wiroatmodjo, A. Abdullah, I,G.M.Tantra, and A. Soegiarto. 1993. Condition, socio-economic values and environ-mental significance of mangrove areas. In: Clough, B.F. 1993. The Economic and environmental values of mangrove forests and their present state of conservation in the South-East Asia/Pacific Region. p. 17-38 Mangrove Ecosystems Technical Reports vol.3 ITTO/ISME/JIAM Project PD71/89. Rev. 1(F) Okinawa, Japan, ISME. 202 pp.

Soeroyo and D. Sapulete., 1994. Potensi Jenisjenis Mangrove Komersial di Teluk Bintuni Irian Jaya. Perairan Maluku dan sekitarnya. Balai Penelitian dan Pengembangan Sumber daya Laut Pusat Penelitian Oseanologi LIPI.6:11-17.

Son, N.T., C.F. Chen, N.B. Chang, C.R. Chen, L.Y. Chang, and B.X.Thanh. 2015. Mangrove Mapping and Change Detection in $\mathrm{Ca} \mathrm{Mau}$ Peninsula, Vietnam, Using Landsat Data and Object-Based Image Analysis. IEEE Journal of Selected Topics in Applied Earth Observation and Remote Sensing.8 (2): 503-510.

Song, C., C.E. Woodcock, K.C. Seto, M.P. Lenney, and S.A Macomber. 2001. Classification and Change Detection Using Landsat TM Data: When and How to Correct Atmospheric Effects?. Remote Sens. Environ. 75:230-244.

Soselisa, A. 2006. Kajian pengelolaan sumberdaya pesisir dan laut Gugusan Pulau Pulau Padaido, Kabupaten Biak-Numfor, Papua. Disertasi Doktor, Program Studi Ilmu Pengelolaan Sumber Daya Pesisir dan Lautan.

Sudtongkong, C., S.K. Oh, and P. Intacharoen. 2013 Geographical information system assessment of mangrove area changes under state versus community management in two communities in Trang province, southern Thailand. Maejo Int. J. Sci. Technol. 2013, 7(Special Issue), 85-95

Sukarjo, S., and D.M., Alongi. 2012. Mangrove of the SouthChina Sea: Ecology and Human Aspects of Indonesia's forest. Nova Science Publisher Inc.

Sulistiyowati, H. 2009. Bodiversitas mangrove di cagar alam Pulau Sempu. Jurnal Sainstek.8(1):59-63.

Supriyadi, H.I. dan S. Wouthuyzen. 2001. Pengelolaan mangrove dan kepiting bakau (Scylla serata) di Pesisr Teluk Kotania, Seram Barat, Maluku Tengah. Oseanologi dan Limnologi di Indonesia33:41-62.

Supriyadi, H.I. dan S. Wouthuyzen. 2005. Penelitian ekonomi sumber daya mangrove di Teluk Kotania, Seram Barat, Propinsi Maluku, Oseanologi dan Limnologi di Indonesia 35:1-21.

Suzana, B.O.L., J. Timban, R. Kaunang, and F.R., Ahmad, F. 2011. Valuasi ekonomi sumberdaya hutan mangrove di Desa Palaes, Kecamatan Likupang Barat, Kabupaten Minahasa Utara. ASE 7(2): 29-38.

Waas, H.J.D. dan B. Nababan. 2010. Pemetaan dan analisis indeks vegetasi mangrove di Pulau Saparua, Maluku Tengah.E-Jurnal Ilmu dan Teknologi Kelautan Tropis2 (1): 50-58.

U.S. Geological Survey and National Oceanic and Atmospheric Adminis-tration, 1984. Landsat4 Data Users Handbook, EROS Data Center, Sioux Falls, South Dakota, 200 p.

Warpur, M. 2016. Struktur vegetasi hutan mangrove dan pemanfaatannya di Kampung Ababiaidi, Distrik Supiori Selatan, Kabupater Supiori. Jurnal Biodjati1(1):1926.

Wartaputra, 1990. Kebijakan Pengelolaan Hutan Mangrove Ditinjau dari Sudut Konservasi Proseding Seminar Eko-sistem Mangrove IV. Bandar Lampung. 7 - 9 Agustus 1990. Panitia MAB, LIPI, Jakarta. Hal $17-24$.

Woodroffe, C.D., 1987. Pacific Island mangrove: Distribution and environmental setting. Paciffic Science4(1-4):166-185.

Wouthuyzen, S., K. Gotoh, N. Kawahara and T. Shichijoh. 1990. Evaluation of mangrove condition in the coastal areas of Kotania Bay, Maluku Province, Indonesia Using Ladndsat MSS data. Procedings of Civil Engineering in the Ocean6:49-52. 
Wouthuyzen, S. 1991. Analysis of the potential utility of remote sensing data from earth observing satellite for monitoring the coastal zone environment. Doctoral Dissertation of Graduate School of marine of science and engineering, Nagasaki University (unpublished 158p).

Wouthuyzen, S. dan D. Sapulete. 1995. Keadaan Wilayah pesisir di Teluk Kotania, Seram barat pada masa lalu dan sekarang: Suatu tinjauan. Perairan Maluku dan Sekitarnya 7:1-10.

Wouthuyzen, S. 1997. Pemantauan hutan mangrove di Teluk Kayeli, Pulau Buru dengan menggunakan data digital citra satelit Landas-5 TM. Seminar kelautan LIPI-UNHAS, Ambon 4-6 Juli 1997, $157-$ 168.

Wouthuyzen, S., H.I. Supriadi, dan F.S. Pulumahuny, 2002. Pemantauan, evaluasi dan pengelolaan sumber daya mangrove di wilayah pesisir Teluk Kotania, dan Teluk Kayeli, Maluku Tengah menggunakan multi-temporal data citra satelit Landsat. Seminar Nasional Limnologi 2002. Bogor 22, April 2002. 211-224.
Wouthuyzen, S., Hindarti, D., Yulianto, K., Hermanto, B., Abrar, M., Mira, S., Triyono, Sita, R., Novianty, H., Arvita R, Umar, A., Nikijuluw, I., Mansur, A., Suhardi, Gunadi, Reza, Wahyu, Hasyim, Hasan, Mumu, dan Dede. 2009. Evaluasi status ekosistem dan sumberdaya hayati laut di Pulau Pari, Kepulauan Seribu. UPT Loka Pengembangan Kompetensi Sumber Daya Manusia Oseanografi, Pulau Pari - LIPI. 83 hal.

Wouthuyzen, S. 2011. Aplication of ALOS AVNIR-2 Images for Assessing and managing the coastal zone resources in Indonesia. Final Report of Principal Investigator (PI) No: 325 submitted to JAXA, Japan. 12 pp.

Wouthuyzen, S., M. Ferianita, B. Fachrul, R. Hakim, F.D. Hukom and H. Purnama. 2014. Long-term monitoring of mangroves conversion along the nothern coast of West Java Province, Indonesia using multitemporal Landsat satellite images. GISUP 2014 (International), No.16, pp.3-13, February 19-21, 2014 